\title{
Angiogenesis and chronic kidney disease
}

\author{
Yohei Maeshima*, Hirofumi Makino
}

\begin{abstract}
The number of patients requiring renal replacement therapy due to end-stage renal disease (ESRD) is increasing worldwide. The prevalence of chronic kidney disease (CKD), and the importance of CKD as a risk factor in development of ESRD and in complicating cardiovascular disease (CVD) have been confirmed. In recent years, the involvement of angiogenesis-related factors in the progression of CKD has been studied, and the potential therapeutic effects on CKD of modulating these factors have been identified. Vascular endothelial growth factor (VEGF)-A, a potent pro-angiogenic factor, is involved in the development of the kidney, in maintenance of the glomerular capillary structure and filtration barrier, and in the renal repair process after injury. VEGF-A is also involved in the development of early diabetic nephropathy, demonstrated by the therapeutic effects of anti-VEGF-A antibody. Angiopoietin (Ang)-1 induces the maturation of newly formed blood vessels, and the therapeutic effects of Ang-1 in diabetic nephropathy have been described. In experimental models of diabetic nephropathy, the therapeutic effects of angiogenesis inhibitors, including angiostatin, endostatin and tumstatin peptides, the isocoumarin NM-3, and vasohibin-1, have been reported.

Further analysis of the involvement of angiogenesis-related factors in the development of CKD is required. Determining the disease stage at which therapy is most effective and developing an effective drug delivery system targeting the kidney will be essential for pro-or anti-angiogenic strategies for patients with CKD.
\end{abstract}

\section{Introduction}

The number of patients with chronic kidney disease (CKD) progressing to end-stage renal disease (ESRD) and requiring renal replacement therapy is increasing worldwide. CKD currently affects over 20 million adults in the USA and over 13 million adults in Japan [1,2]. Of the various renal disorders predisposing to CKD, including glomerulonephritis and hypertensive nephrosclerosis, diabetic nephropathy is the most frequent cause of ESRD development.

Angiogenesis - the development of new blood vessels from pre-existing ones - is involved in physiological events and in pathological disorders including tumor growth and metastasis, proliferative retinopathy, rheumatoid arthritis, psoriasis and neointimal formation [3]. Angiogenesis is controlled by the balance between proangiogenic and anti-angiogenic factors. Angiogenesisassociated factors are involved in the development of the kidney [4-6]. Recent experimental studies have demonstrated the involvement of an imbalance of angiogenesis-related factors in the progression of CKD [7-13], and the potential therapeutic effects on CKD of modulating these factors have been identified [14-22]. Vascular endothelial growth factor (VEGF)-A, a potent pro-angiogenic factor, is involved in the development of the kidney $[4,5]$, and also plays an important role in maintaining the glomerular capillary structure and in the repair process following injuries of glomerular endothelial cells and peritubular capillaries (PTC) $[14,15,17]$. Physiological levels of VEGF-A are also required for maintenance of the glomerular filtration barrier [23]. In the early stages of diabetic nephropathy, increases in the number of glomerular capillaries and in the glomerular levels of VEGF-A and its receptor VEGFR-2 are observed [10,24]. The therapeutic effects of anti-VEGF-A strategies and anti-angiogenic factors in diabetic nephropathy have been reported [19-21,25-30].

In this review, the biological function of angiogenesisassociated factors in CKD and the therapeutic potential of modulating these factors are summarized.

\footnotetext{
* Correspondence: ymaeshim@md.okayama-u.ac.jp Department of Medicine and Clinical Science, Okayama University Graduate School of Medicine, Dentistry and Pharmaceutical Sciences, Okayama, Japan Full list of author information is available at the end of the article
} 


\section{Role of VEGF-A, VEGFR and other angiogenic growth factors in healthy kidney}

A number of angiogenic growth factors are involved in the development of the kidney and in the maintenance of glomerular structures and the glomerular filtration barrier function in adults. Physiological levels of angiogenic factors such as VEGF-A and angiopoietin (Ang)-1 are crucial for maintaining intact glomerular structures and glomerular filtration function. In some cases, proteinuria and endothelial dysfunction may be complicated by excessive inhibition of these factors (for example, treatment with anti-VEGF antibodies in patients with malignancy). In this section, the roles of VEGF-A, VEGFRs and other angiogenic factors including angiopoietins in the healthy kidney are reviewed (Table 1).

\section{VEGF-A}

The role of VEGF-A in regulating angiogenesis has been intensively investigated. VEGF-A signaling is crucially involved in physiological and pathological angiogenesis (for example tumor growth) [31]. The VEGF gene family consists of VEGF-A, VEGF-B, VEGF-C and placental growth factor (PlGF) [31]. VEGF-A is a key regulator of blood vessel growth, whereas VEGF-C and VEGF-D are involved in regulating lymphatic angiogenesis [32]). Inactivation of a single Vegf allele in mice resulted in embryonic lethality, owing to multiple developmental anomalies including defective vascularization in several organs, suggesting an essential role of VEGF in embryonic vasculogenesis and angiogenesis [33,34]. VEGF-A induces the proliferation of endothelial cells in vitro [31], induces angiogenic response in vivo [35], and also induces the survival of endothelial cells [36]. VEGF-A affects vascular permeability [37] and promotes monocyte chemotaxis [38], leading to inflammation and other pathological consequences. VEGF-A also induces endothelium-dependent vasodilatation, in association with endothelium-derived nitric oxide (NO) [39]. Consistent with its role in regulating vascular permeability, VEGF-A induces fenestration of endothelial cells in some vascular beds, including glomerular endothelial cells [40].

Several different splice variant isoforms of VEGF-A $\left(\mathrm{VEGF}_{121}, \mathrm{VEGF}_{165}, \mathrm{VEGF}_{165 \mathrm{~b}}, \mathrm{VEGF}_{189}, \mathrm{VEGF}_{206}\right)$ have been reported [41-43]. The properties of native VEGF-A (45 kDa) closely correspond to those of predominant isoform, VEGF 165 [44]. Expression of VEGF-A mRNA is induced under hypoxic conditions in endothelial cells, mediated through hypoxia-inducible factor (HIF)-1 [45]. In addition, growth factors such as transforming growth factor (TGF)- $\alpha$, TGF- $\beta$, insulin-like growth factor (IGF)-1, platelet-derived growth factor (PDGF) and basic fibroblast growth factor upregulate the expression of VEGF-A mRNA [31].

VEGF-A binds to the tyrosine kinase receptors VEGFR-1 (also known as Flt-1) and VEGFR-2 (also known as KDR/Flk-1) [31], and VEGF-C and VEGF-D bind to VEGFR-3 [32]. VEGF-A also binds to a family of co-receptors, the neuropilins [46]. $\mathrm{VEGF}_{165 \mathrm{~b}}$ antagonizes the effects of VEGF-A, and exerts anti-angiogenic effects [43].

VEGF-A is constitutively expressed in the human kidney, primarily in the glomerular visceral epithelial cells (podocytes) and in tubular epithelial cells in the outer medulla and medullary rays, more commonly observed in distal tubules and collecting ducts than in proximal

Table 1 Expression and biological roles of angiogenic factors in health and CKD

\begin{tabular}{|c|c|c|c|c|}
\hline & Healthy kidney & $\begin{array}{l}\text { Human CKD (non- } \\
\text { diabetic) }\end{array}$ & $\begin{array}{c}\text { Diabetic } \\
\text { nephropathy }\end{array}$ & Therapeutic effects \\
\hline VEGF-A & $\begin{array}{l}\text { Podocyte (h, } m, r) \text {, } \\
\text { TEC (h) }\end{array}$ & Decreased (renal) & $\begin{array}{l}\text { Decreased }(h), \\
\text { Increased }(h, m \text {, } \\
r)\end{array}$ & $\begin{array}{l}\text { Anti-Thy1 nephritis }(r) \text {, anti-GBM nephritis }(r) \text {, thrombotic } \\
\text { microangiopathy }(r) \text {, remnant kidney }(r)\end{array}$ \\
\hline VEGFR-1 & GEnC $(h, m)$, PTC $(h)$ & $\begin{array}{l}\text { MC (Mesangio- } \\
\text { proliferative GN) }\end{array}$ & $\mathrm{NE}$ & NE \\
\hline VEGFR-2 & $\begin{array}{c}\text { GEnC (h, m), podocyte }(m), \\
\text { MC (h), PTC }(h)\end{array}$ & $\begin{array}{l}\text { MC (Mesangio- } \\
\text { proliferative GN) }\end{array}$ & Increased $(r)$ & NE \\
\hline sVEGFR-1 & $\mathrm{NE}$ & $\begin{array}{l}\text { Increased: pre-eclampsia, } \\
\text { CKD (serum) }\end{array}$ & NE & Diabetic nephropathy (m) \\
\hline $\begin{array}{l}\text { Neuropilin- } \\
\quad 1\end{array}$ & $\begin{array}{l}\text { GEnC (h), podocyte (h), MC } \\
\text { (h), TEC (m) }\end{array}$ & NE & NE & NE \\
\hline Ang-1 & podocyte $(h, m)$ & Decreased: CKD (serum) & $\begin{array}{l}\text { Decreased }(r ; \\
\quad \text { renal) }\end{array}$ & Obstructive uropathy (m), diabetic nephropathy (m) \\
\hline Ang-2 & TEC $(m)$ & Increased: CKD (serum) & $\begin{array}{l}\text { Increased (h; } \\
\text { serum), } \\
\text { increased ( } r, m ; \\
\text { renal) }\end{array}$ & NE \\
\hline
\end{tabular}

Ang-1 = angiopoietin-1; Ang-2 = angiopoietin-2; CKD = chronic kidney disease; GEnC = glomerular endothelial cells; GBM = glomerular basement membrane; $\mathrm{GN}=$ glomerulonephritis; $\mathrm{h}=$ human; $\mathrm{m}=$ mouse; $\mathrm{MC}=$ mesangial cell; $\mathrm{NE}=$ not examined; $\mathrm{PTC}=$ peritubular capillaries; $\mathrm{r}=$ rat; $\mathrm{TEC}=$ tubular epithelial cells. 
tubules $[47,48]$. VEGF-A is also expressed in mesangial cells in vitro [49] and in disease models, but not in mesangial cells of the healthy human kidney [47]. Podocyte-specific heterozygous deletion of VEGF-A in mice resulted in proteinuria and glomerular endothelial injury similar to pre-eclampsia, and podocyte-specific overexpression of VEGF-A led to collapsing glomerulopathy, similar to the lesions observed in HIV-associated nephropathy [23]. Therefore, physiological levels of VEGF-A are required for maintenance of the glomerular filtration barrier [23]. In newborn mice, blockade of VEGF-A with antibodies resulted in abnormal glomeruli lacking capillary tufts and in decreased nephron number, suggesting a pivotal role for VEGF-A in the development of glomerular vascular structures [4]. Transgenic rabbits expressing human VEGF $_{165}$ in both the kidney and liver exhibited proteinuria and progressive renal dysfunction, with glomerular hypertrophy and proliferation of mesangial and glomerular endothelial cells [50]. At a later stage, these transgenic rabbits developed microaneurysms, leading to glomerulosclerosis, glomerular cyst formation and tubulointerstitial injuries [50]. More recently, interstitial fibrosis, tubular cyst formation, proliferative enlargement of glomerular capillaries and mesangial proliferation were observed in transgenic adult mice with tubule-specific overexpression of VEGF-A [51]. Veron et al. induced podocytespecific overexpression of VEGF-A in adult mice. The authors observed proteinuria, glomerulomegaly, thickening of the glomerular basement membrane (GBM), mesangial expansion, and podocyte injuries in these mice, similar to the findings observed in diabetic nephropathy [52].

In patients with cancer treated with bevacizumab, a humanized monoclonal anti-VEGF-A antibody, thrombotic microangiopathy developed as a complication. Podocyte-specific deletion of VEGF-A in adult mice produced similar histological lesions [53]. Similar effects of anti-VEGF-A strategies in healthy mice, leading to endothelial dysfunction and proteinuria have been reported [54]. Collectively, the physiological level of VEGF-A is important for the maintenance of renal structures and of an intact filtration barrier in the developing and adult kidney.

$\mathrm{VEGF}_{165 \mathrm{~b}}$, an inhibitory splice variant of VEGF-A, is produced by cultured human podocytes [55]. DenysDrash syndrome is a rare urogenital disorder characterized by male pseudohermaphroditism. It carries a high risk for Wilms' tumor and diffuse mesangial sclerosis, caused by mutations affecting the zinc finger structure of the Wilms' tumor protein 1 [56]. Podocytes obtained from patients with Denys-Drash syndrome express high levels of $\mathrm{VEGF}_{165}$, but lack $\mathrm{VEGF}_{165 \mathrm{~b}}$, potentially associated with the development of glomerulosclerosis [57].

\section{VEGFR-1 (Flt-1)}

VEGF-B and PlGF do not bind to VEGFR-2, but like VEGF-A, they do bind to VEGFR-1. Upon binding to VEGF-A, VEGFR-1 undergoes weak tyrosine autophosphorylation [58]. A soluble extracellular domain of VEGFR-1 (sFlt-1) serves as a VEGF inhibitor [59]. VEGFR-1 ${ }^{-1-}$ mice die in utero at embryonic days (E)8.59.5, primarily due to excessive proliferation of angioblasts, suggesting that VEGFR-1 negatively regulates the activity of VEGF-A, at least during early development [60].

In the healthy human adult kidney, VEGFR-1 is expressed in the endothelia of glomeruli, PTC, and preand post-glomerular vessels $[61,62]$. In cultured mouse podocytes under differentiation conditions, mRNA and protein expression of VEGFR-1 have been reported [63]. In mouse glomeruli, VEGFR-1 has been detected in endothelial cells, but not in podocytes under immunoelectron microscopy [64].

\section{VEGFR-2 (KDR/FIk-1)}

VEGFR-2, a high-affinity receptor of VEGF, serves as an important mediator of VEGF-A in inducing mitogenesis, angiogenesis and vascular permeability [65]. VEGFR-2null mice die in utero, primarily due to a lack of vasculogenesis and failure to develop blood islands and organized blood vessels, suggesting a pivotal role for VEGFR-2 in developmental angiogenesis and hematopoiesis [66]. Upon binding of VEGF-A, VEGFR-2 undergoes dimerization and tyrosine phosphorylation, and phosphorylates several proteins in endothelial cells such as phospholipase $\mathrm{C}-\gamma$, phosphoinositide 3-kinase (PI3K), Ras GTPase-activating protein and Src $[67,68]$. VEGF-A induces endothelial cell proliferation by activating the Raf-MEK-extracellular signal-regulated (ERK) pathway [69]. Activation of VEGFR-2 prevents apoptosis of endothelial cells through activating PI3K-Akt [36].

In the healthy human adult kidney, VEGFR-2, like VEGFR-1 is expressed in the endothelia of glomeruli, PTC and in pre- and post-glomerular vessels $[61,62]$ and weakly on mesangial cells $[61,70]$. No expression of VEGFR-2, either at the mRNA or protein level, was observed in cultured mouse podocytes under differentiation conditions [63]. In mouse glomeruli, VEGFR-2 was detected in endothelial cells and also in podocytes (localized to podocyte cell body and foot processes) by immunoelectron microscopy [64].

Considering the dominant production of VEGF-A by podocytes and the localization of VEGFR-2 on glomerular endothelial cells, it is possible that VEGF-A moves across the GBM, opposing the ultrafiltration gradient to move water and solutes from the capillaries into the Bowman's space. Katavetin et al. recently demonstrated a kinetic model for VEGF-A transport against glomerular filtration flow [71]. Owing to the size selectivity of 
the slit diaphragm in the GBM, VEGF-A secreted by podocyte foot processes accumulates in the subslit space and generates a concentration gradient across the GBM, resulting in the diffusion of VEGF-A from podocytes across the GBM to the endothelial cells [71].

\section{Neuropilin}

Neuropilin is implicated in neuronal guidance, and enhances VEGF $_{165}$-mediated chemotaxis [46]. Neuropilin binds to VEGF 165 in an isoform-specific manner, presenting VEGF $_{165}$ to VEGFR-2 and enhancing the signaling mediated by VEGFR-2 [46]. Neuropilin-1-null mice exhibit embryonic lethality, demonstrating the role of neuropilin-1 in the development of the vascular system [72].

In the healthy human adult kidney, neuropilin-1 is expressed in podocytes, mesangial cells and endothelia of the glomeruli and the afferent arterioles [70,73]. Neuropillin-1 also mediates VEGF-A-induced renal tubular epithelial morphogenesis in mice [74].

\section{Angiopoietins}

The angiopoietin family comprises four structurally related proteins. Ang-1, Ang-2, Ang-3 and Ang-4 [75]. Ang- 1 consistently activates and tyrosine-phosphorylates the receptor Tie-2 on endothelial cells, causing enhanced endothelial cell survival and endothelial cellcell stabilization [76]. Activation of Tie-2 indirectly recruits mesenchymal cells, probably through the action of endothelia-derived paracrine factors, inducing attachment to endothelial tube and differentiation to pericytes, resulting in mature, 'non-leaky' blood vessels [77]. Ang2, a natural antagonist of Ang-1, loosens the attachment of pericytes, resulting in promotion of sprouting angiogenesis in the presence of VEGF-A [78]. When insufficient angiogenic signals are present, Ang-2 causes endothelial cell death and vessel regression [78]. Ang-2 inhibits activation of Tie-2, and can even specifically block Ang-1-dependent phosphorylation [78]. More recently, activation of Tie- 2 by high concentrations of Ang-2 was reported, demonstrating the biological role of Ang- 2 not only in antagonizing Ang-1, but also in maintaining a level of Tie- 2 activation [79]. Tie-1 is widely expressed by developing endothelia, and it downregulates intracellular signaling triggered by Ang-1induced phosphorylation of Tie-2 [80]. Mice deficient in Ang-1 die at E12.5, exhibiting some defects in vascular maturation [77], and mice deficient in Ang-2 die 2 weeks after birth, exhibiting some defects in retinal vascularization and lymphatic function [81]. These results indicate the crucial roles of angiopoietins during normal vascular development in the phases of vascular differentiation and maturation. During kidney development, Ang-1, Ang-2, Tie-1 and Tie-2 are strongly expressed, and play pivotal roles in the maturation of glomeruli and renal blood vessels [6].

Ang-1 is expressed in nephrogenic mesenchyme, differentiating tubular epithelia and mature podocytes in humans and rodents [82,83]. Ang-2 is transiently expressed in renal arterial smooth muscle and mesangial cells during development, and is expressed in mature tubules near the vasa rectae in mice [84]. Transgenic mice with inducible overexpression of Ang-2 in adulthood, specifically in podocytes, exhibited glomerular endothelial apoptosis and reduction in the levels of VEGF-A and nephrin, accompanied by albuminuria [85], suggesting that upregulation of Ang-2 may destabilize glomerular endothelia and indirectly affect podocytes, leading to deterioration of the glomerular filtration barrier function. Expression of Ang-2 is upregulated by hypoxia, HIF-1 $\alpha$, VEGF-A, angiotensin-II, leptin and glucose in bovine microvascular endothelial cells [86]. Sonic hedgehog upregulates the expression of both Ang1 and Ang-2 [87]. By contrast, very little is known about the regulatory mechanism of Ang-1.

\section{Ephrins}

The Eph family of receptor tyrosine kinases and their corresponding ligands (ephrins) were originally identified during studies to determine embryonic patterning and neuronal targeting [88]. EphA receptors bind to the ephrinA ligands, and EphB receptors bind to ephrinB ligands, with the exception of EphA4, which binds to both ephrin types [89]. Mice deficient in ephrinB2 or EphB4 die during embryogenesis with severe cardiovascular defects, suggesting the involvement in the primary capillary network remodeling and patterning in embryonic vasculatures [90,91]. The reciprocal expression pattern of ephrinB2 and EphB4 in arterial and venous endothelial cells suggests that they might interact at the arteriovenous interface [92]. EphA2 was observed in tumor-associated vascular endothelial cells, ephrinA1 was detected in tumor and endothelial cells, and soluble EhpA2-Fc exhibits anti-angiogenic and anti-tumor effects, suggesting their involvement in tumor angiogenesis [93].

During mouse kidney development, ephrin-B2 is expressed initially in a subset of podocyte progenitors and subsequently in endothelial cells of the developing glomerulus, while expression of EphB4 was observed in endothelial cells of venous structures [94], suggesting the involvement of interaction between ephrin-B2 and EphB in glomerular microvascular assembly. In the adult mouse kidney, mRNA for EphA1, A2, B4 and ephrin A1 and B1 were found to be strongly expressed [95]. EphB2 was localized in the medullary tubules, and EphB6 in the tubules of the medulla and cortex [96]. By contrast, ephrin-B1 was detected in tubules of the whole 
mouse nephron [96]. In adult rat glomerulus, ephrin-B1 was found localized at the slit diaphragm, and colocalized with nephrin, a key slit diaphragm protein regulating the glomerular filtration barrier [97]. The role of ephrin-B1 on podocytes in maintaining glomerular filtration barrier function has also been demonstrated [97].

\section{Role of VEGF-A, VEGFR and other angiogenic growth factors in CKD, both diabetic and non- diabetic}

In animal models of non-diabetic CKD including glomerulonephritis, glomerular endothelial cell injuries accompany mesangial alterations or extracapillary lesions. In these models, angiogenic stimuli are required to promote glomerular endothelial repair in association with accelerated resolution of nephritic alterations. In patients in the advanced stages of glomerulonephritis or any other type of renal disorder including hypertensionassociated nephrosclerosis and diabetic nephropathy, glomerulosclerosis and tubulointerstitial injuries are observed. In such cases, angiogenic stimuli may also be required, because the rarefaction of PTC and the resulting tubular hypoxia worsen tubulointerstitial injuries. In diabetic nephropathy, especially in the early stages, excessive angiogenic signals are associated with renal alterations and proteinuria in both humans and animals. Therefore, the role of angiogenesis in renal disorders may vary depending on the type and the stage of disease (Table 1).

\section{VEGF-A and VEGFR}

\section{In non-diabetic CKD}

Proliferation of mesangial cells and expansion of mesangial matrix are central features in various types of glomerular disorders [98,99]. In many forms of glomerulonephritis, severe glomerular injuries are accompanied by glomerular capillary destruction and endothelial cell injuries. Anti-Thy-1 nephritis is one of the widely used models of mesangioproliferative glomerulonephritis [100]. Murine monoclonal 1-22-3 antibody binds to the mesangial cell surface, causing proteinuria and histological alterations, characterized by mesangiolysis followed by monocyte infiltration, mesangial cell proliferation and accumulation of mesangial matrix [101]. In the early phase of rat anti-Thy-1 nephritis following mesangiolysis, reduction in the number of glomerular endothelial cells is observed, followed by initiation of the angiogenic glomerular capillary repair process $[102,103]$. The essential role of VEGF-A in promoting glomerular capillary repair has been reported in rat antiThy-1 nephritis $[14,16]$ and in the rat anti-GBM antibody-induced glomerulonephritis model [15]. In addition, in this model, overexpression of soluble (s)VEGFR1 accelerated the progression of glomerulosclerosis and interstitial fibrosis accompanied by renal dysfunction and PTC loss [7], further supporting the important role of VEGF-A in the maintenance and repair of glomerular endothelia. The mechanism involved in accelerated glomerulosclerosis in sVEGFR-1-treated nephritic rats might involve indirect effects on mesangial cells due to impaired repair of glomerular endothelial cells in the presence of downregulated VEGF-A.

Progressive loss of endothelia in glomeruli and PTC is observed in advanced stages of CKD with renal dysfunction. Reduced or absent expression of VEGF-A was observed in a variety of advanced CKD in humans [104]. Reduction in renal levels of VEGF-A in association with PTC loss was also observed in animal models, including the thrombotic microangiopathy model [18], in the remnant kidney model induced by $5 / 6$ nephrectomy [17], and in the unilateral ureteral obstruction model [105]. Treatment with VEGF-A resulted in the recovery of PTC number, associated with amelioration of tubulointerstitial injuries in the thrombotic microangiopathy and the remnant kidney models $[17,18]$.

VEGFR-1 was observed in mesangial cells in biopsies taken from patients with mesangioproliferative glomerulonephritis [70]. The monocyte-macrophage lineage cells expressed VEGFR-1, and a VEGFR-1 neutralizing monoclonal antibody significantly suppressed VEGF-Ainduced migration of the monocytes, suggesting the involvement of VEGFR-1 in monocyte infiltration [106].

Pre-eclampsia remains a major cause of human maternal and fetal morbidity and mortality, affecting about 5\% of pregnancies [107]. Although the precise mechanism of this disease remains unclear, dysfunction in the maternal vascular endothelium plays a crucial role in the development of pre-eclampsia, resulting in hypertension and proteinuria [108]. Previous studies have suggested that inadequate placental development might lead to placental ischemia, resulting in the release of placental factors that damage the maternal vascular endothelium [109]. Recent reports have demonstrated the involvement of angiogenesis-associated factors in pre-eclampsia. Alterations in the serum level of VEGF-A and decreases in the level of circulating PIGF in patients with pre-eclampsia have been reported [110-112]. The levels of sVEGFR-1, a naturally occurring antagonist of VEGF-A, in amniotic fluid were increased in women with pre-eclampsia [113], and increased production of sVEGFR-1 by cytotrophoblasts isolated from women with pre-eclampsia has been reported [114]. More recently, increases in the level of circulating sVEGFR-1 in women with pre-eclampsia have been reported $[112,115]$. In patients with CKD, excess circulating sVEGFR-1 levels were associated with endothelial dysfunction, suggesting that increased sVEGFR-1 levels may predict cardiovascular risk in CKD [116]. 
Similarly, VEGFR-2 was found in mesangial cells in biopsies taken from patients with mesangioproliferative glomerulonephritis [70]. In patients with focal segmental glomerulosclerosis, tubulointerstitial levels of neuropilin2 were increased, and these correlated with progressive decline in renal function [117].

\section{In diabetic nephropathy}

Diabetic nephropathy is a complication that occurs in $30-40 \%$ of patients with type 2 diabetes, and is the most common pathological disorder predisposing to ESRD in Japan and in western countries [118]. Early alterations in diabetic nephropathy include glomerular hyperfiltration, glomerular and tubular epithelial hypertrophy, and development of microalbuminuria [119]. These early alterations are followed by the development of GBM thickening, accumulation of extracellular matrix (ECM) components in mesangium and interstitium, and increase in excretion of urinary albumin, eventually leading to glomerulosclerosis and progressive loss of renal function $[99,120]$. Involvement of angiotensin II, IGF-I and TGF- $\beta^{1}$ in the development of diabetic nephropathy has been reported $[121,122]$.

In patients with type 1 or 2 diabetic nephropathy, histological alterations with abnormal blood vessels in the glomeruli have been reported [123-125]. The abnormal vessels were seen in the glomerular capillary area, Bowman's capsule and the glomerular vascular pole $[123,124,126]$. Previous studies with rodent models of type 1 and 2 diabetes have demonstrated that the increased glomerular filtration surface in diabetic nephropathy results from the formation of new glomerular capillaries, as well as a slight elongation of the pre-existing capillaries $[24,127]$, analogous to the changes observed in pathologic diabetic retinopathy.

Protein and mRNA level of VEGF-A and VEGFR-2 were found to be upregulated in the early and late stages of rat experimental diabetic nephropathy $[10,128]$. In patients with diabetic nephropathy, plasma [129] and urinary [130] levels of VEGF-A were elevated. In renal biopsies from patients with diabetic nephropathy, glomerular levels of VEGF-A were either increased $[124,131]$ or decreased [132], and tubulointerstitial levels of VEGF-A were reduced [133]. These discrepancies in the glomerular levels of VEGF-A may be attributable to the stage of diabetic nephropathy; that is, reduced renal VEGF-A levels in the advanced stages of disease.

In cultured podocytes, high levels of glucose, TGF- $\beta 1$ and angiotensin-II induce expression of VEGF-A [134]. VEGF-A, produced by podocytes, acts through VEGFR1 also located on podocytes and activates PI3K, leading to increased production of $\alpha 3(\mathrm{IV})$ collagen, a principal component of the GBM, suggesting an autocrine role for VEGF-A [63]. These results suggest a role for TGF- $\beta 1$-induced endogenous VEGF-A in podocyte dysfunction, GBM thickening and alteration of the glomerular filtration barrier in diabetic nephropathy. VEGF-A also decreases intracellular calcium concentration, and exerts protective effects against cytotoxic insult [135].

To address the discrepancies in function of VEGF-A in non-diabetic CKD and diabetic nephropathy, Nakagawa et al. proposed the hypothesis of 'uncoupling of the VEGF-endothelial NO axis' in diabetic nephropathy [136]. Endothelial dysfunction induced by hyperglycemia or other factors may underlie the pathogenic mechanisms of an elevated VEGF state. VEGF-A normally stimulates endothelial NO release and acts as a trophic factor for vascular endothelium in concert with elevated NO levels. The increased NO derived from the endothelial cells prevents excessive proliferation of endothelial and vascular smooth muscle cells and infiltration of monocytes/macrophages. When NO bioavailability is reduced, as in diabetes, elevated levels of VEGF-A lead to excessive endothelial cell proliferation, stimulation of macrophage infiltration and activation of vascular smooth muscle cells. Consistent with this hypothesis, diabetes induced in endothelial NO-deficient mice resulted in clinical and histological features identical to human diabetic nephropathy [137]. The role of VEGF-A in promoting macrophage infiltration through VEGFR-1 and the inhibitory effects of NO on VEGF-A-induced macrophage infiltration were also demonstrated in diabetic endothelial nitric oxide synthase knockout mice [138].

\section{Angiopoietins \\ In non-diabetic CKD}

Futrakul et al. reported reduction in circulating levels of VEGF-A and Ang-1, and elevation of Ang-2 levels in patients with CKD who had moderate to severe renal dysfunction [139]. In a mouse model of folic acidinduced nephrotoxicity, Ang-1 was detected in renal arterial walls and in injured cortical distal tubules [11]. In a mouse anti-GBM nephritis model, the glomerular level of Ang-1 was reduced and Ang-2 was increased, in association with glomerular endothelial cell apoptosis [12]. In a mouse model of unilateral ureteral obstruction, reduction in renal Ang-1 level was observed. Ang-1 gene therapy in this mouse model, using an adenoviral vector encoding a chimeric form of Ang-1 called cartilage oligomeric matrix protein (COMP)-Ang-1, resulted in preservation of $\mathrm{PTC}$ and reductions in monocyte/macrophage infiltration and interstitial fibrosis [22]. In a mouse folic acid-induced nephrotoxicity model, adenoviral delivery of Ang-1 resulted in stabilization of PTC, but also induced inflammatory and fibrotic responses in the kidney [140], suggesting that Ang-1 supplementation can have variable outcomes on renal injuries, depending on 
the disease model. Some recent studies demonstrated that Ang-1 could have pro-inflammatory effects. Murine macrophages expressed Tie-1 and Tie-2 in vitro [140], neutrophils also expressed Tie-2 [141], and treatment of aortic rings with Ang-1 upregulated chemokines [142].

In a rat angiotensin-II infusion model, renal levels of VEGF-A, Ang-1 and Ang-2 were increased via angiotensin-II type 1 and 2 receptors [143]. In the same rat model, we observed an increase in the renal Ang-1:Ang2 ratio, potentially counteracting VEGF-A-induced vascular permeability after infusion of angiotensin-II [144]. In addition, murine macrophages express Ang-2, and this has been implicated in the aggravation of inflammation [145]. Pharmacological blockade of the renin-angiotensin system ameliorated the pathological changes seen in rat anti-Thy-1 nephritis [146]; however, infusion of angiotensin-II before the induction of rat anti-Thy-1 nephritis unexpectedly resulted in accelerated resolution of nephritic alterations in the early stages [147]. In the same rat model, we observed accelerated repair of glomerular endothelium accompanied by renal induction of VEGF-A signaling and increase in the Ang-1:Ang-2 ratio [148].

We have observed elevated serum Ang-2 level in healthy pregnant women compared with non-pregnant women, and significant suppression of circulating Ang-2 in women with pre-eclampsia [149]. The serum Ang-2 concentrations inversely correlated with proteinuria in women with pre-eclampsia [149]. These findings suggest an essential role for Ang-2 in placental angiogenesis during pregnancy.

\section{In diabetic nephropathy}

In patients with type 2 diabetes, elevated circulating levels of Ang-2 and VEGF-A were observed [150]. In a rat model of type 1 diabetic nephropathy, decreased renal level of Ang-1 and elevation of Ang-2 were observed at 8 weeks after the induction of diabetes and Ang-2 was observed in glomerular endothelia and podocytes [13]. We also observed upregulation of renal Ang2 levels and decreased Ang-1/Ang-2 ratio accompanied by glomerular monocyte/macrophage infiltration in mouse type 1 and 2 diabetic nephropathy models [25-27]. In a mouse model of obese type 2 diabetes, Ang-1 gene therapy using adenoviral vector encoding COMP-Ang-1 resulted in the reduction in albuminuria, amelioration of mesangial expansion and podocyte injuries accompanied by reduced monocyte/macrophage infiltration and downregulation of chemokines and adhesion molecules [151].

\section{Other angiogenic factors}

In a mouse model of ischemia-reperfusion injury (IRI), renal expression of EphA2 mRNA was markedly increased and EphA2 protein was detected in distal tubules [95]. Interactions between EphA2 and its ephrin ligands may be involved in cytoskeletal repair of tubular epithelial cells in renal IRI.

PIGF, a member of VEGF family, stimulates pathological angiogenesis through activating VEGFR-1 without any influence on physiological processes [152]. In the early stages ( 1 or 2 weeks) of the rat remnant kidney model, renal levels of PIGF were elevated in association with enhanced angiogenic response [153]. Whether VEGF-A [17] or PIGF play principal roles in the angiogenic repair process after injuries induced by renal mass ablation needs further investigation.

\section{Role of angiogenesis inhibitors in CKD, both diabetic and non-diabetic}

Although findings about the biological role of angiogenesis inhibitors in CKD are relatively limited, therapeutic effects have been reported for angiogenesis inhibitors in experimental diabetic nephropathy models. Angiogenesis inhibitors exhibit therapeutic effects on diabetic nephropathy by anti-angiogenic and anti-inflammatory mechanisms, as inhibition of excessive neovessels may reduce the infiltration of inflammatory cells, and downregulation of VEGF-A may ameliorate vascular permeability. However, considering the reduction in PTC density associated with tubular hypoxia and tubulointerstitial injuries in advanced CKD, use of angiogenesis inhibitors may need careful consideration.

\section{Angiogenesis inhibitors in non-diabetic CKD Angiostatin}

Angiostatin, a proteolytic fragment of plasminogen, potently blocks neovascularization, tumor growth and metastasis [154]. In healthy rat kidney, angiostatin is not expressed, but its level was enhanced in the first 3 days after renal IRI, and remained detectable until 35 days after induction of ischemia-reperfusion (I/R) [155]. Renal angiostatin generation after acute renal failure induced by I/R may modulate postischemic renal capillary density and thereby influence chronic renal dysfunction.

In a rat remnant kidney model, pretreatment with adenoassociated viral vectors encoding angiostatin resulted in reduction in PTC density and urinary $\mathrm{NO}$ levels [156]; however, in another study, interstitial fibrosis and monocyte infiltration was ameliorated by treatment with angiostatin [156]. Therefore, angiostatin may exert therapeutic effects in CKD through its anti-inflammatory actions, but potential adverse events (such as reducing PTC through its anti-angiogenic effects, thus leading to the acceleration of tubular hypoxia/ischemia) have to be considered. 


\section{Angiogenesis inhibitors in diabetic nephropathy Anti-VEGF-A therapies}

As described in the previous section, renal levels of VEGF-A and VEGFR-2 were increased in both early and late stages of rat experimental diabetic nephropathy [10,128]. Animal studies using monoclonal anti-VEGF-A antibodies have demonstrated the involvement of VEGF-A in early glomerular hypertrophy and mesangial matrix accumulation during the progressive stages of diabetic nephropathy $[19,20]$. In addition, SU5416, a pan-VEGF receptor tyrosine kinase inhibitor, reduced albuminuria in the type 2 diabetes $\mathrm{db} / \mathrm{db}$ mouse model [21]. Podocyte-specific, doxycycline-inducible overexpression of sVEGFR-1 in adult mice ameliorated diabetic glomerular injuries, further implicating the involvement of VEGF-A in the pathogenesis of diabetic nephropathy [64].

\section{Tumstatin}

Type IV collagen is expressed as six distinct $\alpha$-chains ( $\alpha 1$ to $\alpha 6$ ), assembles into triple helices, and forms organized networks. The $\alpha$-chains consist of an N-terminal $7 \mathrm{~S}$ domain, a central collagenous triple helical domain and a C-terminal globular NC1 domain. Although the $\alpha 1(\mathrm{IV})$ and $\alpha 2$ (IV) chains are ubiquitously distributed in human basement membranes, distribution of the $\alpha 3$ (IV) chain is limited to certain basement membranes, such as GBM, several basement membranes of the cochlea, and the alveolar capillary basement membrane [157].

$\alpha 3$ (IV)NC1 (also known as tumstatin, a term derived from its unique property of causing 'tumor-stasis'), inhibits angiogenesis and tumor growth by suppression of endothelial cell proliferation and tube formation [158-160]. Representative matrix-derived angiogenesis inhibitors are listed in Table 2. Tumstatin exerts its anti-angiogenic effects by binding to $\alpha v \beta 3$ integrin in an Arg-Gly-Asp (RGD)-independent manner [161,162].

Goodpasture syndrome is an autoimmune disease characterized by pulmonary hemorrhage and/or rapidly progressive glomerulonephritis. The most probable disease-related pathogenic autoepitope was identified in the tumstatin sequence [163], within the $\mathrm{N}$-terminal 40 amino acids [164]. Using deletion mutants of tumstatin and synthetic peptides, the domain possessing antiangiogenic properties was found to be confined to the T3 (69-88 amino acids), T7 (74-98 amino acids) and T8 peptide regions of tumstatin, outside the Goodpasture epitope $[165,166]$.

Apoptosis is regulated in part at the level of protein synthesis, and is generally associated with inhibition of cap-dependent protein translation. Tumstatin peptides exhibit endothelial cell-specific inhibitory effects on capdependent translation by negatively regulating activation of focal adhesion kinase (FAK), PI3K, Akt, mTOR and eukaryotic initiation factor $4 \mathrm{E}$ binding protein 1 [167]. These inhibitory effects of tumstatin peptides were not observed in $\beta 3$-integrin-deficient endothelial cells, implying an interaction of tumstatin peptides with $\alpha v \beta 3$ integrin-induced negative regulatory signals counteracting growth factor-initiated cell survival signals [167].

Because histological 'angiogenic' abnormal vessels in the glomerular capillary area, Bowman's capsule and the glomerular vascular pole are observed in the early stages of diabetic nephropathy in both humans and rodents $[24,123,124,127]$, and the involvement of VEGF-A was demonstrated in the progression of experimental diabetic nephropathy $[19,20]$, we hypothesized that antiangiogenic factors might inhibit the progression of diabetic nephropathy. To test this hypothesis, we examined the therapeutic effect of tumstatin in the early stages of

Table 2 Endogenous basement membrane-derived angiogenesis inhibitors

\begin{tabular}{|c|c|c|c|c|}
\hline $\begin{array}{l}\text { Angiogenesis } \\
\text { inhibitor }\end{array}$ & Parent protein & Domain & Receptors & Inhibitory activities on EC \\
\hline Endostatin & $\begin{array}{l}\alpha 1 \text { chain of type XVIII } \\
\text { collagen }\end{array}$ & $\mathrm{NC1}$ & $\begin{array}{l}\text { Glypicans, flk-1, } \alpha 5 \beta 1- \\
\text { integrin }\end{array}$ & $\begin{array}{l}\text { Proliferation, migration, tube formation, survival, tumor } \\
\text { growth }\end{array}$ \\
\hline Restin & $\begin{array}{l}\alpha 1 \text { chain of type } X V \\
\text { collagen }\end{array}$ & NC10 & Unknown & Proliferation, migration, tumor growth \\
\hline Tumstatin & $\begin{array}{l}\alpha 3 \text { chain of type IV } \\
\text { collagen }\end{array}$ & $\mathrm{NC} 1$ & $\alpha \vee \beta 3$-integrin & $\begin{array}{c}\text { Proliferation, tube formation, survival, protein translation, } \\
\text { tumor growth }\end{array}$ \\
\hline Arresten & $\begin{array}{l}\alpha 1 \text { chain of type IV } \\
\text { collagen }\end{array}$ & $\mathrm{NC1}$ & $\alpha 1 \beta 1$-integrin & $\begin{array}{l}\text { Proliferation, migration, tube formation, survival, tumor } \\
\text { growth }\end{array}$ \\
\hline Canstatin & $\begin{array}{l}\alpha 2 \text { chain of type IV } \\
\text { collagen }\end{array}$ & $\mathrm{NC} 1$ & $\alpha 3 \beta 1$-integrin & $\begin{array}{l}\text { Proliferation, migration, tube formation, survival, tumor } \\
\text { growth }\end{array}$ \\
\hline$\alpha 6(\mathrm{IV}) \mathrm{NC} 1$ & $\begin{array}{l}\alpha 6 \text { chain of type IV } \\
\text { collagen }\end{array}$ & $\mathrm{NC} 1$ & Unknown & Proliferation \\
\hline Endorepellin & Perlecan & $\begin{array}{l}\text { Domain } \\
\qquad\end{array}$ & $\alpha 2 \beta 1$-integrin & $\begin{array}{l}\text { Migration, tube formation, survival, blood vessel growth in } \\
\text { vivo }\end{array}$ \\
\hline
\end{tabular}

EC, endothelial cell. ECM, extracellular matrix. 
diabetic nephropathy in the streptozotocin (STZ)induced mouse type 1 diabetes model [25]. Treatment with the tumstatin T8 peptide did not affect hyperglycemia, but significantly suppressed renal hypertrophy, glomerular hypertrophy/hyperfiltration and albuminuria, and histological alterations such as mesangial expansion, increase in glomerular capillary number and monocyte/ macrophage infiltration in diabetic animals. The tumstatin (T8) peptide significantly suppressed the STZinduced increase in VEGF-A and VEGFR-2 in the renal cortex, suggesting that the therapeutic effect of the tumstatin (T8) peptide in early diabetic nephropathy may be at least partly attributable to the inhibition of excessive activation of VEGF-A signaling, analogous to previous studies using neutralizing anti-VEGF-A antibodies $[19,20]$. The tumstatin (T8) peptide treatment did not affect the renal levels of Ang1, but suppressed Ang-2 increase in diabetic mice, leading to elevation of the Ang-1:Ang-2 ratio [25]. The marked increase in Ang-2 over Ang-1 in diabetic mice suggests that there is a proangiogenic environment, considering the simultaneous upregulation of VEGF-A and the unstable, 'leaky' condition of capillaries, possibly associated with inflammatory responses such as monocyte/macrophage recruitment.

Nephrin is a podocyte protein crucial for maintenance of an intact glomerular filtration barrier [168]. In diabetic nephropathy, the protein level of nephrin decreases in association with podocyte injury and proteinuria, and tumstatin restored the level of nephrin, possibly associated with its anti-albuminuric effects [25]. The indirect influence of glomerular endothelial cells toward podocytes possibly mediated via secreted factors or alteration on matrix microenvironment, might be involved in this mechanism.

Collectively, these results suggest that the tumstatin peptide may have therapeutic potential in human diabetic nephropathy, in addition to its potent anti-tumor effect.

\section{Endostatin}

Endostatin, a $20 \mathrm{kDa}$ C-terminal NC1 domain of type XVIII collagen, possesses potent anti-angiogenic activity [169]. Endostatin was initially isolated from the conditioned medium of murine hemangioendothelioma cells. Endostatin inhibits endothelial cell proliferation, migration and tube formation in vitro $[170,171]$, and possesses potent inhibitory effects on tumor growth in vivo. The inhibitory effects of endostatin on the expression of VEGF in tumor cells and on vascular permeability have been reported [172]. The therapeutic potential of endostatin in non-neoplastic disorders with involvement of angiogenic processes (for example, rheumatoid arthritis, proliferative diabetic retinopathy and peritoneal sclerosis) has also been reported [173-175]. The anti-angiogenic activity of endostatin was confined to the peptide region within the $\mathrm{N}$-terminal domain [176].
Human endostatin interacts with $\alpha 5 \beta 1$ integrin, leading to the inhibition of the activation of FAK and subsequent inhibition of mitogen-activated protein kinases (MAPKs) including ERK-1/2 and p38MAPK, resulting in inhibition of endothelial cell migration [177]. In addition, glypicans, a form of heparan sulfate glycosaminoglycans, bind to endostatin, and this interaction is important for mediating the anti-angiogenic activities of endostatin in vitro [178].

We examined the therapeutic effects of endostatin in the early stages of diabetic nephropathy utilizing the STZ-induced mouse type 1 diabetes model [26]. Although treatment with a synthetic endostatin peptide encompassing the 1-27 amino acid portion of human endostatin did not affect hyperglycemia in this model, there was significant suppression of renal hypertrophy, glomerular hypertrophy/hyperfiltration and albuminuria, along with histological alterations [26]. The endostatin peptide significantly suppressed the STZ-induced increase in VEGF-A, VEGFR-2, Ang-2, TGF- $\beta 1$, IL-6 and monocyte chemotactic protein (MCP)- 1 in renal cortex and restored the level of nephrin [26]. Because a central involvement of $\alpha 5 \beta 1$ integrin in mediating the anti-angiogenic capacity of endostatin has been reported [177], we studied the localization of this cell surface receptor in diabetic mice. Although expression of $\alpha 5 \beta 1$ integrin was faintly present in the glomeruli of non-diabetic control mice, increased expression of $\alpha 5 \beta 1$ integrin colocalized with CD31 was observed in the glomeruli of diabetic mice, as detected by double immunofluorescence [26]. These results suggest that the primary action of endostatin on glomerular endothelial cells mediated via $\alpha 5 \beta 1$ integrin in diabetic mice. Therefore, we speculate that endostatin indirectly affects podocytes leading to decreased expression of VEGF-A in diabetic mice.

\section{NM-3}

2-(8-hydroxy-6-methoxy-1-oxo-1H-2-benzopyran-3-yl) propionic acid (NM-3) is a synthetic derivative of cytogenin, a natural compound isolated from filtrates of Streptoverticillium eurocidicum cultures [179]. NM-3 potently inhibits endothelial cell proliferation, migration, sprouting and tube formation in vitro and tumor growth in vivo [180]. Moreover, NM-3 suppresses endothelial cell migration induced by VEGF-A, and exerts inhibitory effects on angiogenesis in VEGF-A-secreting malignant tumors [180]. A phase I clinical study of NM-3 in patients with cancer has demonstrated that NM-3 has high oral bioavailability and is a well-tolerated drug in humans [181].

We examined the therapeutic effect of NM-3 on longterm renal alterations in $\mathrm{db} / \mathrm{db}$ mice, a model of obese type 2 diabetes [27]. Treatment with NM-3 was initiated at 8 weeks of age in $\mathrm{db} / \mathrm{db}$ mice exhibiting hyperglycemia 
and was continued until 16 weeks. Although treatment with NM-3 did not affected either obesity or hyperglycemia, significant suppression of renal hypertrophy, glomerular hypertrophy/hyperfiltration and albuminuria, as well as histological alterations were observed in diabetic animals [27]. NM-3 significantly suppressed the increase in VEGF-A, Ang-2, TGF- $\beta 1$ and MCP- 1 seen in the renal cortex, and restored the level of nephrin in $\mathrm{db} / \mathrm{db}$ mice [27]. The direct inhibitory effect of NM-3 on phosphorylation of VEGFR-2 in glomerular endothelial cells remains to be elucidated. However, inhibitory effects of NM-3 on renal levels of VEGF-A suggest a potential inhibitory effect of NM-3 on the phosphorylation of VEGFR2 in glomerular endothelial cells, resulting in the observed therapeutic effects of NM-3 in diabetic mice. In vitro analysis further demonstrated the direct inhibitory effect of NM-3 on the synthesis of TGF- $\beta$ in mesangial cells and the production of VEGF-A in podocytes induced by high glucose [27]. These results demonstrate the direct effect of NM-3 on mesangial cells and podocytes under high glucose conditions, in addition to its known effects on endothelial cells, and the efficacy of angiogenesis inhibitors on long-term renal alterations in obese type 2 diabetes.

\section{Angiostatin}

Angiostatin inhibits retinal neovascularization and reduces retinal vascular permeability in diabetic retinopathy. Zhang et al. examined the potential involvement of angiostatin in diabetic nephropathy using an STZinduced type 1 diabetes rat model [28]. Angiostatin levels were dramatically decreased in the kidneys of control diabetic rats, and adenovirus-mediated delivery of angiostatin significantly ameliorated albuminuria and glomerular hypertrophy in diabetic rats. Inhibitory effects of angiostatin treatment on VEGF-A and TGF- $\beta 1$ in diabetic kidneys were also observed [28]. In cell culture analysis, angiostatin blocked overexpression of VEGF-A and TGF- $\beta 1$ induced by high levels of glucose, while increasing the levels of pigment epitheliumderived factor (PEDF), an endogenous inhibitor of diabetic nephropathy. Similar to NM-3, angiostatin produced direct effects on mesangial cells and endothelial cells, as well as therapeutic effects on diabetic nephropathy.

\section{PEDF}

PEDF is a potent inhibitor of angiogenesis, and decreased ocular levels of PEDF are associated with diabetic retinopathy. Wang et al. have demonstrated that renal expression of PEDF was decreased in the STZinduced type 1 diabetic rat model, and high levels of glucose significantly decreased PEDF secretion in primary human mesangial cells (HMC) in vitro [182]. PEDF blocked the overexpression of TGF- $\beta$ and fibronectin induced by high glucose levels in primary HMC
[182]. Wang et al. also showed that adenoviral delivery of PEDF into the kidney significantly ameliorated microalbuminuria in the early stages of diabetes by suppressing TGF- $\beta 1$ and connective tissue growth factor and enhancing MMP-2, thus leading to reduced production of ECM proteins in the diabetic kidney [29]. They further demonstrated the anti-inflammatory action of PEDF therapy in the same model; PEDF regulated renal levels of intracellular adhesion molecule-1, MCP-1, TNF- $\beta$ and VEGF-A, and it also inhibited activation of the transcription factors nuclear factor kappa $B$ and HIF-1 in mesangial cells [183].

\section{Vasohibin-1}

Vasohibin (VASH)-1, an endogenous angiogenesis inhibitor, was identified in a microarray analysis assessing genes upregulated by VEGF-A in endothelial cells [184]. VASH-1 serves as an endothelial cell-derived negative feedback regulator of angiogenesis, and its therapeutic efficacies on tumor growth, atherosclerosis and proliferative retinopathy models have been reported [184-186]. The potential of VASH-1 as a biomarker of disorders associated with angiogenesis was demonstrated for endometrial cancer and rheumatoid arthritis $[187,188]$. We recently reported the therapeutic effects of VASH-1 in the mouse STZ-induced type 1 diabetic nephropathy model [30]. Mice were given intravenous injections of adenoviral vectors encoding VASH-1 (AdhVASH-1) every 2 weeks. Treatment with AdhVASH-1 resulted in sustained increase in the circulating levels of VASH-1, and significantly suppressed renal and glomerular hypertrophy, glomerular hyperfiltration, albuminuria, increase in the CD31+ glomerular endothelial area and F4/80+ monocyte/macrophage infiltration, and accumulation of type IV collagen and mesangial matrix compared with AdLacZ-treated diabetic mice at 4 weeks after initiating treatment [30]. Interestingly, VASH-1 treatment did not affect the microvascular density of PTC in diabetic animals. Increase in the renal levels of TGF- $\beta 1, \mathrm{MCP}-1$ and RAGE (receptor for advanced glycation end products) in diabetic animals was significantly suppressed by AdhVASH-1. VASH-1 further suppressed increase in TGF- $\beta 1$, MCP- 1 and RAGE induced by high glucose levels in cultured mouse mesangial cells. Increased phosphorylation of VEGFR2 was suppressed in the kidneys of AdhVASH-1-treated diabetic animals and in cultured glomerular endothelial cells [30]. Endogenous mouse VASH-1 was localized to the mesangial and endothelial areas in glomeruli of diabetic mice. These results suggest therapeutic potential for VASH-1 in treating early diabetic nephropathy thought to be mediated via glomerular endothelial and mesangial cells (Figure 1). We recently observed potential protective effects of VASH-1 on glomerular podocytes, possibly 


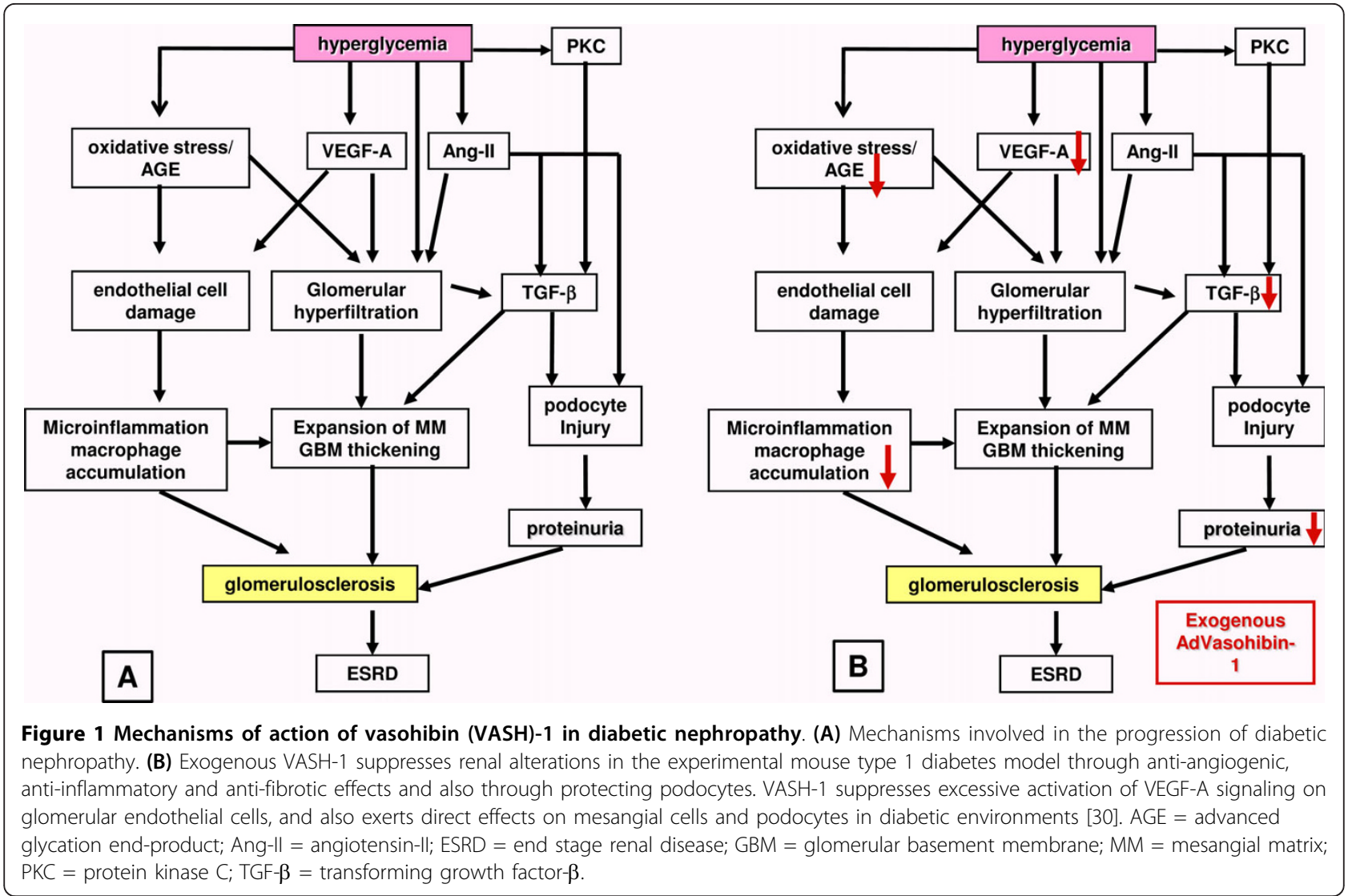

associated with anti-albuminuric effect (manuscript in submission).

Levels of endogenousVASH-1 are decreased in proliferating endothelial cells at the sprouting front, but are elevated in non-proliferating endothelial cells at the termination zone of angiogenesis, presumably serving to halt angiogenesis [189]. VASH-2, a homologue of VASH-1, was identified subsequently, and is mainly derived from infiltrating mononuclear cells mobilized from bone marrow, which infiltrate the sprouting front. Levels of endogenous VASH-2 are elevated at the sprouting front, but are low at the termination zone of angiogenesis, presumably serving to induce angiogenesis [189]. Exogenous VASH-1 inhibited angiogenesis at the sprouting front, where endogenous VASH-1 was scarce, but did not influence vascularity in the termination zone, where endogenous VASH-1 was high [189]. Exogenous VASH-2 prevented the termination of angiogenesis, and increased vascularity in the termination zone [189]. Angiogenesis was persistent in the termination zone in VASH-1 knockout mice, but was deficient at the sprouting front in VASH-2 knockout mice [189]. Regulation of the balance between VASH-1 and VASH2 may be involved in angiogenesis and vascular maturation, and may be involved in the progression and the control of CKD (Figure 2).

\section{Potential problems in using anti-angiogenic therapies in patients with CKD}

The potential adverse events of bevacizumab, a humanized monoclonal antibody against VEGF-A have been reported in patients with cancer, with administration of the drug resulting in thrombotic microangiopathy [53]. The lack of such histological alterations in previous experimental diabetic nephropathy models treated with anti-VEGF antibodies or SU5416 [19-21], and amelioration of diabetic glomerular alterations by inducible podocyte-specific overexpression of sVEGFR-1 in adult mice [64] suggest that anti-VEGF-A therapy might not be detrimental for patients with diabetic nephropathy. In fact, systemic delivery of sVEGFR-1 resulted in the protection of podocytes and a reduction in albuminuria, but exacerbated tubulointerstitial injuries accompanied by PTC loss in $\mathrm{db} / \mathrm{db}$ mice [190]. Although tumstatin, endostatin, NM-3 and VASH-1 suppress overactivation of VEGFR-2, they do not serve as specific inhibitors of VEGF-A signaling, unlike bevacizumab or other specific anti-VEGF-A therapeutics. Because PTC loss, chronic 


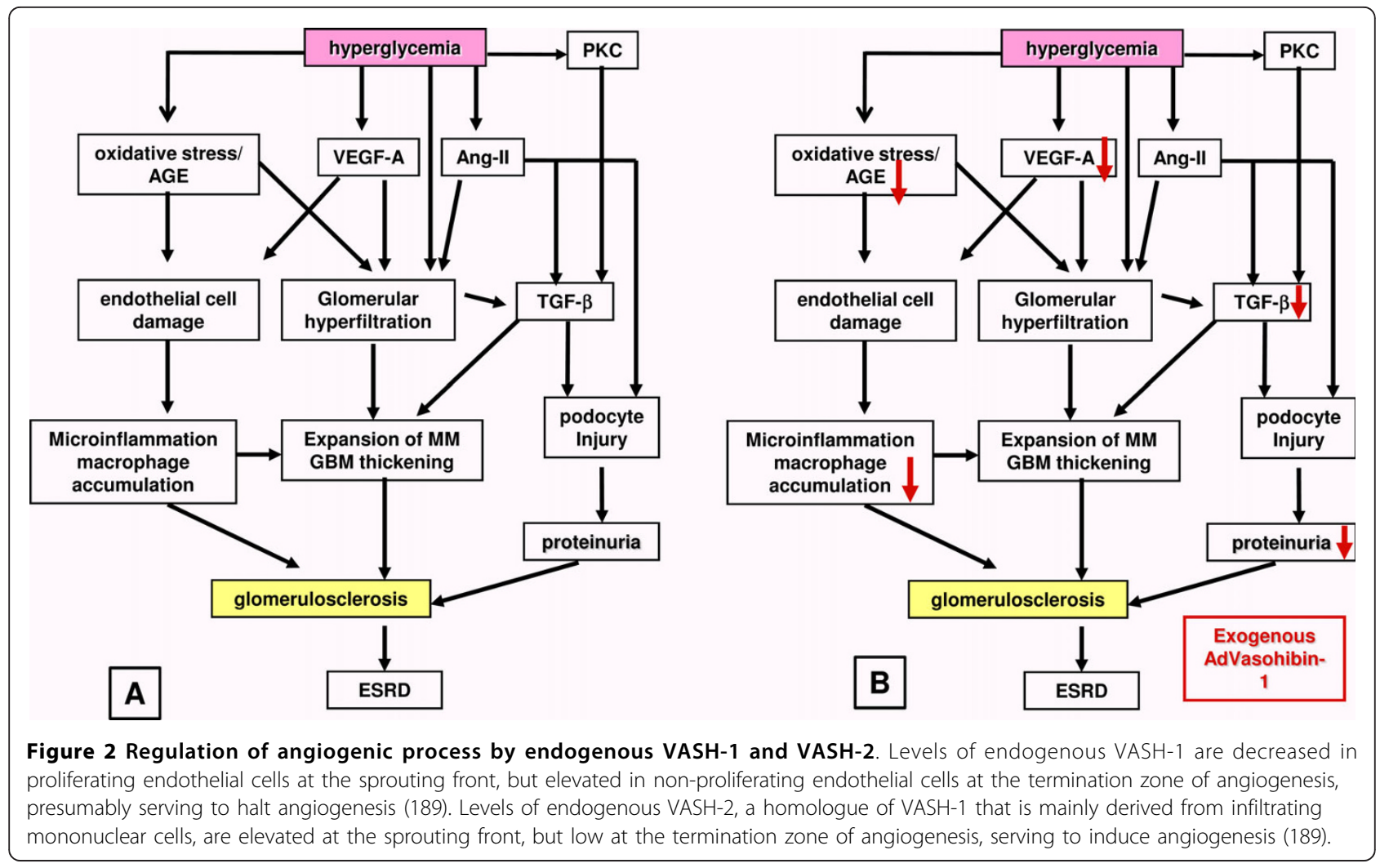

hypoxia or tubulointerstitial injuries are involved in the progression of CKD [191], careful evaluation of patients' long-term outcome after anti-angiogenic therapeutics is required.

In the advanced stages of CKD including diabetic nephropathy, anti-angiogenic reagents may impair neovessel formation, leading to deterioration of macrovascular complications such as myocardial infarction and limb ischemia. Thus, considering the involvement of angiogenesis in atherosclerosis., anti-angiogenic therapeutics might be tolerable or even therapeutic for atherosclerotic conditions. In fact, the therapeutic effects of VASH-1 in preventing neointimal formation have been reported [185]. In addition, VASH-1 does not impair healthy blood or lymphatic vessels in mice [192], suggesting relative safety of this factor in treating patients with diabetic and non-diabetic CKD. Regarding the question of using adenoviral vectors to treat patients with diabetes, potential adverse events such as non-specific inflammatory reactions and the replication of adenoviruses in vivo must be avoided, and further assessments on the safety of this strategy are required.

\section{Conclusion}

We have looked at recent advances on the involvement of angiogenic and antiangiogenic factors in CKD and potential experimental approaches using angiogenesis inhibitors to treat CKD, including diabetic nephropathy. Based on the mechanistic insight into the involvement of angiogenesis in CKD, use of novel therapeutic reagents in patients with CKD in clinical practice is expected in the near future, leading to the eventual reduction in the number of patients developing ESRD.

\section{Acknowledgements}

We are grateful to Professor Raghu Kalluri (Beth Israel Deaconess Medical Center and Harvard Medical School, Boston, USA) for helpful discussion regarding this research area. We are also grateful to all the doctors, fellows and research assistants involved in the research projects described in this article. A portion of this study was supported by a grant in aid for scientific research (Ministry of Education, Science and Culture of Japan for 2002-2010 to $Y M$ ), a grant in aid from the Takeda Science Promotion Foundation of Japan (2006, 2008 to YM), and a grant from the Uchida Cardiology Research Promotion Foundation of Japan (2006 to YM). YM is a recipient of the 2005 Oshima Award (Young Investigator Award) from the Japanese Society of Nephrology.

\section{Authors' contributions}

YM carried out experimental studies and drafted the manuscript. HM participated in the design of experiments and helped to draft the manuscript. All authors read and approved the final manuscript.

\section{Competing interests}

YM and HM have submitted a patent application for treating diabetic nephropathy and peritoneal sclerosis by vasohibin-1.

Received: 18 May 2010 Accepted: 5 August 2010

Published: 5 August 2010 


\section{References}

1. Coresh J, Astor BC, Greene T, Eknoyan G, Levey AS: Prevalence of chronic kidney disease and decreased kidney function in the adult US population: Third National Health and Nutrition Examination Survey. Am J Kidney Dis 2003, 41:1-12.

2. Matsuo S, Imai E, Horio M, Yasuda Y, Tomita K, Nitta K, Yamagata K, Tomino $\mathrm{Y}$, Yokoyama $\mathrm{H}$, Hishida A: Revised equations for estimated GFR from serum creatinine in Japan. Am J Kidney Dis 2009, 53:982-992.

3. Folkman J: Angiogenesis in cancer, vascular, rheumatoid and other disease. Nat Med 1995, 1:27-31.

4. Kitamoto Y, Tokunaga H, Tomita K: Vascular endothelial growth factor is an essential molecule for mouse kidney development: glomerulogenesis and nephrogenesis. J Clin Invest 1997, 99:2351-2357.

5. Tufro A, Norwood VF, Carey RM, Gomez RA: Vascular endothelial growth factor induces nephrogenesis and vasculogenesis. J Am Soc Nephrol 1999, 10:2125-2134.

6. Woolf AS, Yuan HT: Angiopoietin growth factors and Tie receptor tyrosine kinases in renal vascular development. Pediatr Nephrol 2001, 16:177-184.

7. Hara A, Wada T, Furuichi K, Sakai N, Kawachi H, Shimizu F, Shibuya M, Matsushima K, Yokoyama H, Egashira K, Kaneko S: Blockade of VEGF accelerates proteinuria, via decrease in nephrin expression in rat crescentic glomerulonephritis. Kidney Int 2006, 69:1986-1995.

8. Kang DH, Joly AH, Oh SW, Hugo C, Kerjaschki D, Gordon KL, Mazzali M, Jefferson JA, Hughes J, Madsen KM, Schreiner GF, Johnson RJ: Impaired angiogenesis in the remnant kidney model: I. Potential role of vascular endothelial growth factor and thrombospondin-1. J Am Soc Nephrol 2001, 12:1434-1447.

9. Kang DH, Anderson S, Kim YG, Mazzalli M, Suga S, Jefferson JA, Gordon KL, Oyama TT, Hughes J, Hugo C, Kerjaschki D, Schreiner GF, Johnson RJ: Impaired angiogenesis in the aging kidney: vascular endothelial growth factor and thrombospondin-1 in renal disease. Am J Kidney Dis 2001, 37:601-611.

10. Cooper ME, Vranes D, Youssef S, Stacker SA, Cox AJ, Rizkalla B, Casley DJ, Bach LA, Kelly DJ, Gilbert RE: Increased renal expression of vascular endothelial growth factor (VEGF) and its receptor VEGFR-2 in experimental diabetes. Diabetes 1999, 48:2229-2239.

11. Long DA, Woolf AS, Suda T, Yuan HT: Increased renal angiopoietin-1 expression in folic acid-induced nephrotoxicity in mice. J Am Soc Nephrol 2001, 12:2721-2731.

12. Yuan HT, Tipping PG, Li XZ, Long DA, Woolf AS: Angiopoietin correlates with glomerular capillary loss in anti-glomerular basement membrane glomerulonephritis. Kidney Int 2002, 61:2078-2089.

13. Rizkalla B, Forbes JM, Cao Z, Boner G, Cooper ME: Temporal renal expression of angiogenic growth factors and their receptors in experimental diabetes: role of the renin-angiotensin system. $J$ Hypertens 2005, 23:153-164.

14. Masuda $Y$, Shimizu A, Mori T, Ishiwata T, Kitamura H, Ohashi R, Ishizaki M, Asano G, Sugisaki Y, Yamanaka N: Vascular endothelial growth factor enhances glomerular capillary repair and accelerates resolution of experimentally induced glomerulonephritis. Am J Pathol 2001, 159:599-608.

15. Shimizu A, Masuda Y, Mori T, Kitamura H, Ishizaki M, Sugisaki Y, Fukuda Y: Vascular endothelial growth factor165 resolves glomerular inflammation and accelerates glomerular capillary repair in rat anti-glomerular basement membrane glomerulonephritis. J Am Soc Nephrol 2004, 15:2655-2665.

16. Ostendorf $T$, Kunter $U$, Eitner $F$, Loos $A$, Regele $H$, Kerjaschki $D$, Henninger DD, Janjic N, Floege J: VEGF(165) mediates glomerular endothelial repair. J Clin Invest 1999, 104:913-923.

17. Kang DH, Hughes J, Mazzali M, Schreiner GF, Johnson RJ: Impaired angiogenesis in the remnant kidney model: II. Vascular endothelial growth factor administration reduces renal fibrosis and stabilizes renal function. J Am Soc Nephrol 2001, 12:1448-1457.

18. Kim YG, Suga SI, Kang DH, Jefferson JA, Mazzali M, Gordon KL, Matsui K, Breiteneder-Geleff S, Shankland SJ, Hughes J, Kerjaschki D, Schreiner GF, Johnson RJ: Vascular endothelial growth factor accelerates renal recovery in experimental thrombotic microangiopathy. Kidney Int 2000, 58:2390-2399.

19. de Vriese AS, Tilton RG, Elger M, Stephan CC, Kriz W, Lameire NH: Antibodies against vascular endothelial growth factor improve early renal dysfunction in experimental diabetes. J Am Soc Nephrol 2001, 12:993-1000.

20. Flyvbjerg A, Dagnaes-Hansen F, De Vriese AS, Schrijvers BF, Tilton RG, Rasch R: Amelioration of long-term renal changes in obese type 2 diabetic mice by a neutralizing vascular endothelial growth factor antibody. Diabetes 2002, 51:3090-3094.

21. Sung SH, Ziyadeh FN, Wang A, Pyagay PE, Kanwar YS, Chen S: Blockade of vascular endothelial growth factor signaling ameliorates diabetic albuminuria in mice. J Am Soc Nephrol 2006, 17:3093-3104.

22. Kim W, Moon SO, Lee SY, Jang KY, Cho CH, Koh GY, Choi KS, Yoon KH, Sung MJ, Kim DH, Lee S, Kang KP, Park SK: COMP-angiopoietin-1 ameliorates renal fibrosis in a unilateral ureteral obstruction model. J Am Soc Nephrol 2006, 17:2474-2483.

23. Eremina V, Sood M, Haigh J, Nagy A, Lajoie G, Ferrara N, Gerber HP, Kikkawa Y, Miner JH, Quaggin SE: Glomerular-specific alterations of VEGFA expression lead to distinct congenital and acquired renal diseases. J Clin Invest 2003, 111:707-716.

24. Nyengaard JR, Rasch $R$ : The impact of experimental diabetes mellitus in rats on glomerular capillary number and sizes. Diabetologia 1993, 36:189-194.

25. Yamamoto $Y$, Maeshima Y, Kitayama H, Kitamura S, Takazawa Y, Sugiyama H, Yamasaki Y, Makino H: Tumstatin Peptide, an inhibitor of angiogenesis, prevents glomerular hypertrophy in the early stage of diabetic nephropathy. Diabetes 2004, 53:1831-1840.

26. Ichinose $K$, Maeshima $Y$, Yamamoto $Y$, Kitayama H, Takazawa $Y$, Hirokoshi $K$, Sugiyama $H$, Yamasaki $Y$, Eguchi $K$, Makino H: Anti-angiogenic endostatin peptide ameliorates renal alterations in the early stage of type 1 diabetic nephropathy model. Diabetes 2005, 54:in press.

27. Ichinose $K$, Maeshima $Y$, Yamamoto $Y$, Kinomura M, Hirokoshi K, Kitayama H, Takazawa Y, Sugiyama H, Yamasaki Y, Agata N, Makino H: 2-(8-hydroxy-6methoxy-1-oxo-1h-2-benzopyran-3-yl) propionic acid, an inhibitor of angiogenesis, ameliorates renal alterations in obese type 2 diabetic mice. Diabetes 2006, 55:1232-1242.

28. Zhang SX, Wang JJ, Lu K, Mott R, Longeras R, Ma JX: Therapeutic potential of angiostatin in diabetic nephropathy. J Am Soc Nephrol 2006, 17:475-486.

29. Wang JJ, Zhang SX, Mott R, Knapp RR, Cao W, Lau K, Ma JX: Salutary effect of pigment epithelium-derived factor in diabetic nephropathy: evidence for antifibrogenic activities. Diabetes 2006, 55:1678-1685

30. Nasu T, Maeshima Y, Kinomura M, Hirokoshi-Kawahara K, Tanabe K, Sugiyama $H$, Sonoda $H$, Sato $Y$, Makino $H$ : Vasohibin-1, a negative feedback regulator of angiogenesis, ameliorates renal alterations in a mouse model of diabetic nephropathy. Diabetes 2009, 58:2365-2375.

31. Ferrara N, Davis-Smyth T: The biology of vascular endothelial growth factor. Endocr Rev 1997, 18:4-25.

32. Karkkainen MJ, Makinen T, Alitalo K: Lymphatic endothelium: a new frontier of metastasis research. Nat Cell Biol 2002, 4:E2-5.

33. Ferrara N, Carver-Moore K, Chen H, Dowd M, Lu L, O'Shea KS, PowellBraxton L, Hillan KJ, Moore MW: Heterozygous embryonic lethality induced by targeted inactivation of the VEGF gene. Nature 1996, 380:439-442.

34. Carmeliet P, Ferreira V, Breier G, Pollefeyt S, Kieckens L, Gertsenstein M, Fahrig M, Vandenhoeck A, Harpal K, Eberhardt C, Declercq C, Pawling J, Moons L, Collen D, Risau W, Nagy A: Abnormal blood vessel development and lethality in embryos lacking a single VEGF allele. Nature 1996, 380:435-439.

35. Leung DW, Cachianes G, Kuang WJ, Goeddel DV, Ferrara N: Vascular endothelial growth factor is a secreted angiogenic mitogen. Science 1989, 246:1306-1309.

36. Gerber HP, McMurtrey A, Kowalski J, Yan M, Keyt BA, Dixit V, Ferrara N: Vascular endothelial growth factor regulates endothelial cell survival through the phosphatidylinositol 3'-kinase/Akt signal transduction pathway. Requirement for Flk-1/KDR activation. J Biol Chem 1998, 273:30336-30343.

37. Bates DO, Curry FE: Vascular endothelial growth factor increase microvascular permeability via a $\mathrm{Ca}(2+)$-dependent pathway. Am J Physiol 1997, 273:H687-694

38. Barleon B, Sozzani S, Zhou D, Weich HA, Mantovani A, Marme D: Migration of human monocytes in response to vascular endothelial growth factor (VEGF) is mediated via the VEGF receptor flt-1. Blood 1996, 87:3336-3343. 
39. Tilton RG, Chang KC, LeJeune WS, Stephan CC, Brock TA, Williamson JR: Role for nitric oxide in the hyperpermeability and hemodynamic changes induced by intravenous VEGF. Invest Ophthalmol Vis Sci 1999, 40:689-696.

40. Satchell SC, Braet F: Glomerular endothelial cell fenestrations: an integral component of the glomerular filtration barrier. Am J Physiol Renal Physiol 2009, 296:F947-956.

41. Houck KA, Ferrara N, Winer J, Cachianes G, Li B, Leung DW: The vascular endothelial growth factor family: identification of a fourth molecular species and characterization of alternative splicing of RNA. Mol Endocrinol 1991, 5:1806-1814.

42. Tischer E, Mitchell R, Hartman T, Silva M, Gospodarowicz D, Fiddes JC, Abraham JA: The human gene for vascular endothelial growth factor. Multiple protein forms are encoded through alternative exon splicing. J Biol Chem 1991, 266:11947-11954.

43. Bates DO, Cui TG, Doughty JM, Winkler M, Sugiono M, Shields JD, Peat D, Gillatt D, Harper SJ: VEGF165b, an inhibitory splice variant of vascular endothelial growth factor, is down-regulated in renal cell carcinoma. Cancer Res 2002, 62:4123-4131.

44. Park JE, Keller GA, Ferrara N: The vascular endothelial growth factor (VEGF) isoforms: differential deposition into the subepithelial extracellular matrix and bioactivity of extracellular matrix-bound VEGF. Mol Biol Cell 1993, 4:1317-1326.

45. Semenza G: Signal transduction to hypoxia-inducible factor 1. Biochem Pharmacol 2002, 64:993-998.

46. Soker S, Takashima S, Miao HQ, Neufeld G, Klagsbrun M: Neuropilin-1 is expressed by endothelial and tumor cells as an isoform-specific receptor for vascular endothelial growth factor. Cell 1998, 92:735-745.

47. Brown LF, Berse B, Tognazzi K, Manseau EJ, Van de Water L, Senger DR, Dvorak HF, Rosen S: Vascular permeability factor mRNA and protein expression in human kidney. Kidney Int 1992, 42:1457-1461.

48. Kretzler M, Schroppel B, Merkle M, Huber S, Mundel P, Horster M, Schlondorff D: Detection of multiple vascular endothelial growth factor splice isoforms in single glomerular podocytes. Kidney Int Supp/ 1998, 67 S159-161.

49. lijima K, Yoshikawa N, Connolly DT, Nakamura H: Human mesangial cells and peripheral blood mononuclear cells produce vascular permeability factor. Kidney Int 1993, 44:959-966.

50. Liu E, Morimoto M, Kitajima S, Koike T, Yu Y, Shiiki H, Nagata M, Watanabe T, Fan J: Increased expression of vascular endothelial growth factor in kidney leads to progressive impairment of glomerular functions. J Am Soc Nephrol 2007, 18:2094-2104.

51. Hakroush S, Moeller MJ, Theilig F, Kaissling B, Sijmonsma TP, Jugold M, Akeson AL, Traykova-Brauch M, Hosser H, Hahnel B, Grone HJ, Koesters R, Kriz W: Effects of increased renal tubular vascular endothelial growth factor (VEGF) on fibrosis, cyst formation, and glomerular disease. Am J Pathol 2009, 175:1883-1895.

52. Veron D, Reidy KJ, Bertuccio C, Teichman J, Villegas G, Jimenez J, Shen W, Kopp JB, Thomas DB, Tufro A: Overexpression of VEGF-A in podocytes of adult mice causes glomerular disease. Kidney Int 77:989-999.

53. Eremina V, Jefferson JA, Kowalewska J, Hochster $H$, Haas M, Weisstuch J, Richardson C, Kopp JB, Kabir MG, Backx PH, Gerber HP, Ferrara N, Barisoni L, Alpers CE, Quaggin SE: VEGF inhibition and renal thrombotic microangiopathy. N Engl J Med 2008, 358:1129-1136.

54. Sugimoto $H$, Hamano $Y$, Charytan D, Cosgrove D, Kieran M, Sudhakar A, Kalluri R: Neutralization of circulating vascular endothelial growth factor (VEGF) by anti-VEGF antibodies and soluble VEGF receptor 1 (sFlt-1) induces proteinuria. J Biol Chem 2003, 278:12605-12608.

55. Cui TG, Foster RR, Saleem M, Mathieson PW, Gillatt DA, Bates DO, Harper SJ: Differentiated human podocytes endogenously express an inhibitory isoform of vascular endothelial growth factor (VEGF165b) mRNA and protein. Am J Physiol Renal Physiol 2004, 286:F767-773.

56. Drash A, Sherman F, Hartmann WH, Blizzard RM: A syndrome of pseudohermaphroditism, Wilms' tumor, hypertension, and degenerative renal disease. J Pediatr 1970, 76:585-593.

57. Schumacher VA, Jeruschke $S$, Eitner F, Becker JU, Pitschke $G$, Ince $Y$, Miner JH, Leuschner I, Engers R, Everding AS, Bulla M, Royer-Pokora B: Impaired glomerular maturation and lack of VEGF165b in Denys-Drash syndrome. J Am Soc Nephrol 2007, 18:719-729.

58. de Vries C, Escobedo JA, Ueno H, Houck K, Ferrara N, Williams LT: The fmslike tyrosine kinase, a receptor for vascular endothelial growth factor. Science 1992, 255:989-991.
59. Kendall RL, Thomas KA: Inhibition of vascular endothelial cell growth factor activity by an endogenously encoded soluble receptor. Proc Natl Acad Sci USA 1993, 90:10705-10709.

60. Fong GH, Zhang L, Bryce DM, Peng J: Increased hemangioblast commitment, not vascular disorganization, is the primary defect in flt- 1 knock-out mice. Development 1999, 126:3015-3025.

61. Simon M, Grone HJ, Johren O, Kullmer J, Plate KH, Risau W, Fuchs E: Expression of vascular endothelial growth factor and its receptors in human renal ontogenesis and in adult kidney. Am J Physiol 1995, 268 F240-250.

62. Simon M, Rockl W, Hornig C, Grone EF, Theis H, Weich HA, Fuchs E, Yayon A, Grone HJ: Receptors of vascular endothelial growth factor/ vascular permeability factor (VEGF/VPF) in fetal and adult human kidney: localization and [125I]VEGF binding sites. J Am Soc Nephrol 1998, 9:1032-1044.

63. Chen S, Kasama Y, Lee JS, Jim B, Marin M, Ziyadeh FN: Podocyte-derived vascular endothelial growth factor mediates the stimulation of alpha3 (IV) collagen production by transforming growth factor-beta1 in mouse podocytes. Diabetes 2004, 53:2939-2949.

64. Ku CH, White KE, Dei Cas A, Hayward A, Webster Z, Bilous R, Marshall S, Viberti G, Gnudi L: Inducible overexpression of sFlt-1 in podocytes ameliorates glomerulopathy in diabetic mice. Diabetes 2008, 57:2824-2833.

65. Ferrara N, Gerber HP, LeCouter J: The biology of VEGF and its receptors. Nat Med 2003, 9:669-676.

66. Shalaby F, Rossant J, Yamaguchi TP, Gertsenstein M, Wu XF, Breitman ML, Schuh AC: Failure of blood-island formation and vasculogenesis in Flk-1deficient mice. Nature 1995, 376:62-66.

67. Guo D, Jia Q, Song HY, Warren RS, Donner DB: Vascular endothelial cell growth factor promotes tyrosine phosphorylation of mediators of signal transduction that contain $\mathrm{SH} 2$ domains. Association with endothelial cell proliferation. J Biol Chem 1995, 270:6729-6733.

68. Eliceiri BP, Paul R, Schwartzberg PL, Hood JD, Leng J, Cheresh DA: Selective requirement for Src kinases during VEGF-induced angiogenesis and vascular permeability. Mol Cell 1999, 4:915-924.

69. Takahashi T, Ueno H, Shibuya M: VEGF activates protein kinase Cdependent, but Ras-independent Raf-MEK-MAP kinase pathway for DNA synthesis in primary endothelial cells. Oncogene 1999, 18:2221-2230.

70. Thomas S, Vanuystel J, Gruden G, Rodriguez V, Burt D, Gnudi L, Hartley B, Viberti G: Vascular endothelial growth factor receptors in human mesangium in vitro and in glomerular disease. J Am Soc Nephrol 2000, 11:1236-1243.

71. Katavetin P: VEGF inhibition and renal thrombotic microangiopathy. $N$ Engl J Med 2008, 359:205-206, author reply 206-207.

72. Kawasaki T, Kitsukawa T, Bekku Y, Matsuda Y, Sanbo M, Yagi T, Fujisawa H: A requirement for neuropilin-1 in embryonic vessel formation. Development 1999, 126:4895-4902.

73. Harper SJ, Xing CY, Whittle C, Parry R, Gillatt D, Peat D, Mathieson PW: Expression of neuropilin-1 by human glomerular epithelial cells in vitro and in vivo. Clin Sci (Lond) 2001, 101:439-446.

74. Karihaloo A, Karumanchi SA, Cantley WL, Venkatesha S, Cantley LG, Kale S: Vascular endothelial growth factor induces branching morphogenesis/ tubulogenesis in renal epithelial cells in a neuropilin-dependent fashion. Mol Cell Biol 2005, 25:7441-7448.

75. Yancopoulos GD, Davis S, Gale NW, Rudge JS, Wiegand SJ, Holash J: Vascular-specific growth factors and blood vessel formation. Nature 2000 407:242-248

76. Thurston G, Rudge JS, loffe E, Zhou H, Ross L, Croll SD, Glazer N, Holash J, McDonald DM, Yancopoulos GD: Angiopoietin-1 protects the adult vasculature against plasma leakage. Nat Med 2000, 6:460-463.

77. Suri C, Jones PF, Patan S, Bartunkova S, Maisonpierre PC, Davis S, Sato TN, Yancopoulos GD: Requisite role of angiopoietin-1, a ligand for the TIE2 receptor, during embryonic angiogenesis. Cell 1996, 87:1171-1180.

78. Maisonpierre PC, Suri C, Jones PF, Bartunkova S, Wiegand SJ, Radziejewski C, Compton D, McClain J, Aldrich TH, Papadopoulos N, Daly TJ, Davis S, Sato TN, Yancopoulos GD: Angiopoietin-2, a natural antagonist for Tie2 that disrupts in vivo angiogenesis. Science 1997, 277:55-60.

79. Yuan HT, Khankin EV, Karumanchi SA, Parikh SM: Angiopoietin 2 is a partial agonist/antagonist of Tie2 signaling in the endothelium. Mol Cell Biol 2009, 29:2011-2022. 
80. Yuan HT, Venkatesha S, Chan B, Deutsch U, Mammoto T, Sukhatme VP, Woolf AS, Karumanchi SA: Activation of the orphan endothelial receptor Tie1 modifies Tie2-mediated intracellular signaling and cell survival. FASEB J 2007, 21:3171-3183.

81. Gale NW, Thurston G, Hackett SF, Renard R, Wang Q, McClain J, Martin C, Witte C, Witte MH, Jackson D, Suri C, Campochiaro PA, Wiegand SJ, Yancopoulos GD: Angiopoietin-2 is required for postnatal angiogenesis and lymphatic patterning, and only the latter role is rescued by Angiopoietin-1. Dev Cell 2002, 3:411-423.

82. Satchell SC, Harper SJ, Tooke JE, Kerjaschki D, Saleem MA, Mathieson PW: Human podocytes express angiopoietin 1, a potential regulator of glomerular vascular endothelial growth factor. J Am Soc Nephrol 2002, 13:544-550.

83. Woolf AS, Gnudi L, Long DA: Roles of angiopoietins in kidney development and disease. J Am Soc Nephrol 2009, 20:239-244.

84. Yuan HT, Suri C, Landon DN, Yancopoulos GD, Woolf AS: Angiopoietin-2 is a site-specific factor in differentiation of mouse renal vasculature. $J \mathrm{Am}$ Soc Nephrol 2000, 11:1055-1066.

85. Davis B, Dei Cas A, Long DA, White KE, Hayward A, Ku CH, Woolf AS, Bilous R, Viberti G, Gnudi L: Podocyte-specific expression of angiopoietin2 causes proteinuria and apoptosis of glomerular endothelia. J Am SoC Nephrol 2007, 18:2320-2329.

86. Oh H, Takagi H, Suzuma K, Otani A, Matsumura M, Honda Y: Hypoxia and vascular endothelial growth factor selectively up-regulate angiopoietin-2 in bovine microvascular endothelial cells. J Biol Chem 1999, 274:15732-15739.

87. Pola R, Ling LE, Silver M, Corbley MJ, Kearney M, Blake Pepinsky $R$ Shapiro R, Taylor FR, Baker DP, Asahara T, Isner JM: The morphogen Sonic hedgehog is an indirect angiogenic agent upregulating two families of angiogenic growth factors. Nat Med 2001, 7:706-711.

88. Holder N, Klein R: Eph receptors and ephrins: effectors of morphogenesis. Development 1999, 126:2033-2044.

89. Kullander K, Klein R: Mechanisms and functions of Eph and ephrin signalling. Nat Rev Mol Cell Biol 2002, 3:475-486.

90. Gerety SS, Wang HU, Chen ZF, Anderson DJ: Symmetrical mutant phenotypes of the receptor EphB4 and its specific transmembrane ligand ephrin-B2 in cardiovascular development. Mol Cell 1999, 4:403-414.

91. Wang HU, Chen ZF, Anderson DJ: Molecular distinction and angiogenic interaction between embryonic arteries and veins revealed by ephrin-B2 and its receptor Eph-B4. Cell 1998, 93:741-753.

92. Adams RH, Wilkinson GA, Weiss C, Diella F, Gale NW, Deutsch U, Risau W, Klein R: Roles of ephrinB ligands and EphB receptors in cardiovascular development: demarcation of arterial/venous domains, vascular morphogenesis, and sprouting angiogenesis. Genes Dev 1999, 13:295-306.

93. Marme D: The impact of anti-angiogenic agents on cancer therapy. J Cancer Res Clin Oncol 2003, 129:607-620.

94. Takahashi T, Takahashi K, Gerety S, Wang H, Anderson DJ, Daniel TO: Temporally compartmentalized expression of ephrin-B2 during renal glomerular development. J Am Soc Nephrol 2001, 12:2673-2682.

95. Baldwin C, Chen ZW, Bedirian A, Yokota N, Nasr SH, Rabb H, Lemay S: Upregulation of EphA2 during in vivo and in vitro renal ischemiareperfusion injury: role of Src kinases. Am J Physiol Renal Physiol 2006, 291:F960-971.

96. Ogawa K, Wada H, Okada N, Harada I, Nakajima T, Pasquale EB, Tsuyama S: EphB2 and ephrin-B1 expressed in the adult kidney regulate the cytoarchitecture of medullary tubule cells through Rho family GTPases. J Cell Sci 2006, 119:559-570.

97. Hashimoto T, Karasawa T, Saito A, Miyauchi N, Han GD, Hayasaka K, Shimizu F, Kawachi H: Ephrin-B1 localizes at the slit diaphragm of the glomerular podocyte. Kidney Int 2007, 72:954-964.

98. Klahr S, Schreiner G, Ichikawa I: The progression of renal disease. N Engl J Med 1988, 318:1657-1666.

99. Makino H, Kashihara N, Sugiyama H, Kanao K, Sekikawa T, Okamoto K, Maeshima Y, Ota Z, Nagai R: Phenotypic modulation of the mesangium reflected by contractile proteins in diabetes. Diabetes 1996, 45:488-495.

100. Maeshima Y, Kashihara N, Yasuda T, Sugiyama H, Sekikawa T, Okamoto K, Kanao K, Watanabe Y, Kanwar YS, Makino H: Inhibition of mesangial cell proliferation by E2F decoy oligodeoxynucleotide in vitro and in vivo. $J$ Clin Invest 1998, 101:2589-2597.
101. Kawachi H, Oite T, Shimizu F: Quantitative study of mesangial injury with proteinuria induced by monoclonal antibody 1-22-3. Clin Exp Immunol 1993, 92:342-346.

102. Shimizu A, Masuda Y, Kitamura H, Ishizaki M, Sugisaki Y, Yamanaka N: Recovery of damaged glomerular capillary network with endothelial cell apoptosis in experimental proliferative glomerulonephritis. Nephron 1998, 79:206-214.

103. Kriz W, Hahnel B, Hosser H, Ostendorf T, Gaertner S, Kranzlin B, Gretz N, Shimizu F, Floege J: Pathways to recovery and loss of nephrons in antiThy-1 nephritis. J Am Soc Nephrol 2003, 14:1904-1926.

104. Shulman K, Rosen S, Tognazzi K, Manseau EJ, Brown LF: Expression of vascular permeability factor (VPF/NEGF) is altered in many glomerular diseases. J Am Soc Nephrol 1996, 7:661-666.

105. Ohashi R, Shimizu A, Masuda Y, Kitamura H, Ishizaki M, Sugisaki Y, Yamanaka N: Peritubular capillary regression during the progression of experimental obstructive nephropathy. J Am Soc Nephrol 2002, 13:1795-1805.

106. Sawano A, Iwai S, Sakurai Y, Ito M, Shitara K, Nakahata T, Shibuya M: Flt-1, vascular endothelial growth factor receptor 1 , is a novel cell surface marker for the lineage of monocyte-macrophages in humans. Blood 2001, 97:785-791.

107. Roberts JM, Cooper DW: Pathogenesis and genetics of pre-eclampsia. Lancet 2001, 357:53-56.

108. Roberts JM, Taylor RN, Musci TJ, Rodgers GM, Hubel CA, McLaughlin MK Preeclampsia: an endothelial cell disorder. Am J Obstet Gynecol 1989, 161:1200-1204

109. Rodgers GM, Taylor RN, Roberts JM: Preeclampsia is associated with a serum factor cytotoxic to human endothelial cells. Am J Obstet Gynecol 1988, 159:908-914

110. Kupferminc MJ, Daniel Y, Englender T, Baram A, Many A, Jaffa AJ, Gull I, Lessing JB: Vascular endothelial growth factor is increased in patients with preeclampsia. Am J Reprod Immunol 1997, 38:302-306.

111. Livingston JC, Chin R, Haddad B, McKinney ET, Ahokas R, Sibai BM: Reductions of vascular endothelial growth factor and placental growth factor concentrations in severe preeclampsia. Am J Obstet Gynecol 2000, 183:1554-1557.

112. Levine RJ, Maynard SE, Qian C, Lim KH, England LJ, Yu KF, Schisterman EF, Thadhani R, Sachs BP, Epstein FH, Sibai BM, Sukhatme VP, Karumanchi SA: Circulating angiogenic factors and the risk of preeclampsia. N Engl J Med 2004, 350:672-683.

113. Vuorela P, Helske S, Hornig C, Alitalo K, Weich H, Halmesmaki E: Amniotic fluid-soluble vascular endothelial growth factor receptor-1 in preeclampsia. Obstet Gynecol 2000, 95:353-357.

114. Zhou Y, McMaster M, Woo K, Janatpour M, Perry J, Karpanen T, Alitalo K Damsky C, Fisher SJ: Vascular endothelial growth factor ligands and receptors that regulate human cytotrophoblast survival are dysregulated in severe preeclampsia and hemolysis, elevated liver enzymes, and low platelets syndrome. Am J Pathol 2002, 160:1405-1423.

115. Koga K, Osuga Y, Yoshino O, Hirota Y, Ruimeng X, Hirata T, Takeda S, Yano $T$, Tsutsumi $O$, Taketani $Y$ : Elevated serum soluble vascular endothelial growth factor receptor 1 (sVEGFR-1) levels in women with preeclampsia. J Clin Endocrinol Metab 2003, 88:2348-2351.

116. Di Marco GS, Reuter S, Hillebrand U, Amler S, Konig M, Larger E, Oberleithner $\mathrm{H}$, Brand $\mathrm{E}$, Pavenstadt $\mathrm{H}$, Brand M: The soluble VEGF receptor sFlt1 contributes to endothelial dysfunction in CKD. J Am Soc Nephrol 2009, 20:2235-2245.

117. Schramek H, Sarkozi R, Lauterberg C, Kronbichler A, Pirklbauer M, Albrecht R, Noppert SJ, Perco P, Rudnicki M, Strutz FM, Mayer G: Neuropilin-1 and neuropilin-2 are differentially expressed in human proteinuric nephropathies and cytokine-stimulated proximal tubular cells. Lab Invest 2009, 89:1304-1316.

118. Ritz E, Rychlik I, Locatelli F, Halimi S: End-stage renal failure in type 2 diabetes: A medical catastrophe of worldwide dimensions. Am J Kidney Dis 1999, 34:795-808.

119. Osterby R, Parving HH, Nyberg G, Hommel E, Jorgensen $H E$, Lokkegaard $H$, Svalander C: A strong correlation between glomerular filtration rate and filtration surface in diabetic nephropathy. Diabetologia 1988, 31:265-270.

120. Makino H, Yamasaki Y, Haramoto T, Shikata K, Hironaka K, Ota Z, Kanwar YS: Ultrastructural changes of extracellular matrices in diabetic nephropathy 
revealed by high resolution scanning and immunoelectron microscopy Lab Invest 1993, 68:45-55.

121. Sharma K, Ziyadeh FN: Hyperglycemia and diabetic kidney disease. The case for transforming growth factor-beta as a key mediator. Diabetes 1995, 44:1139-1146.

122. Flyvbjerg A: Putative pathophysiological role of growth factors and cytokines in experimental diabetic kidney disease. Diabetologia 2000, 43:1205-1223.

123. Osterby R, Nyberg G: New vessel formation in the renal corpuscles in advanced diabetic glomerulopathy. J Diabet Complications 1987, 1:122-127.

124. Kanesaki Y, Suzuki D, Uehara G, Toyoda M, Katoh T, Sakai H, Watanabe T: Vascular endothelial growth factor gene expression is correlated with glomerular neovascularization in human diabetic nephropathy. Am J Kidney Dis 2005, 45:288-294.

125. Hohenstein B, Hausknecht B, Boehmer K, Riess R, Brekken RA, Hugo CP: Local VEGF activity but not VEGF expression is tightly regulated during diabetic nephropathy in man. Kidney Int 2006, 69:1654-1661.

126. Osterby R, Bangstad HJ, Nyberg G, Rudberg S: On glomerular structural alterations in type- 1 diabetes. Companions of early diabetic glomerulopathy. Virchows Arch 2001, 438:129-135.

127. Guo M, Ricardo SD, Deane JA, Shi M, Cullen-McEwen L, Bertram JF: A stereological study of the renal glomerular vasculature in the $\mathrm{db} / \mathrm{db}$ mouse model of diabetic nephropathy. J Anat 2005, 207:813-821.

128. Tsuchida K, Makita Z, Yamagishi S, Atsumi T, Miyoshi H, Obara S, Ishida M, Ishikawa S, Yasumura K, Koike T: Suppression of transforming growth factor beta and vascular endothelial growth factor in diabetic nephropathy in rats by a novel advanced glycation end product inhibitor, OPB-9195. Diabetologia 1999, 42:579-588.

129. Hovind P, Tarnow L, Oestergaard PB, Parving HH: Elevated vascular endothelial growth factor in type 1 diabetic patients with diabetic nephropathy. Kidney Int Suppl 2000, 75:S56-61.

130. Kim NH, Oh JH, Seo JA, Lee KW, Kim SG, Choi KM, Baik SH, Choi DS, Kang YS, Han SY, Han KH, Ji YH, Cha DR: Vascular endothelial growth factor (VEGF) and soluble VEGF receptor FLT-1 in diabetic nephropathy. Kidney Int 2005, 67:167-177.

131. Cha DR, Kim NH, Yoon JW, Jo SK, Cho WY, Kim HK, Won NH: Role of vascular endothelial growth factor in diabetic nephropathy. Kidney Int Suppl 2000, 77:S104-112.

132. Baelde HJ, Eikmans M, Doran PP, Lappin DW, de Heer E, Bruijn JA: Gene expression profiling in glomeruli from human kidneys with diabetic nephropathy. Am J Kidney Dis 2004, 43:636-650.

133. Lindenmeyer MT, Kretzler M, Boucherot A, Berra S, Yasuda $Y$, Henger $A$, Eichinger F, Gaiser S, Schmid H, Rastaldi MP, Schrier RW, Schlondorff D, Cohen CD: Interstitial vascular rarefaction and reduced VEGF-A expression in human diabetic nephropathy. J Am Soc Nephrol 2007, 18:1765-1776.

134. Wolf G, Chen S, Ziyadeh FN: From the periphery of the glomerular capillary wall toward the center of disease: podocyte injury comes of age in diabetic nephropathy. Diabetes 2005, 54:1626-1634.

135. Foster RR, Hole R, Anderson K, Satchell SC, Coward RJ, Mathieson PW, Gillatt DA, Saleem MA, Bates DO, Harper SJ: Functional evidence that vascular endothelial growth factor may act as an autocrine factor on human podocytes. Am J Physiol Renal Physiol 2003, 284:F1263-1273.

136. Nakagawa T: Uncoupling of the VEGF-endothelial nitric oxide axis in diabetic nephropathy: an explanation for the paradoxical effects of VEGF in renal disease. Am J Physiol Renal Physiol 2007, 292:F1665-1672.

137. Nakagawa T, Sato W, Glushakova O, Heinig M, Clarke T, CampbellThompson M, Yuzawa Y, Atkinson MA, Johnson RJ, Croker B: Diabetic endothelial nitric oxide synthase knockout mice develop advanced diabetic nephropathy. J Am Soc Nephrol 2007, 18:539-550.

138. Sato W, Kosugi T, Zhang L, Roncal CA, Heinig M, Campbell-Thompson M, Yuzawa Y, Atkinson MA, Grant MB, Croker BP, Nakagawa T: The pivotal role of VEGF on glomerular macrophage infiltration in advanced diabetic nephropathy. Lab Invest 2008, 88:949-961.

139. Futrakul N, Butthep P, Futrakul P: Altered vascular homeostasis in chronic kidney disease. Clin Hemorheol Microcirc 2008, 38:201-207.

140. Long DA, Price KL, loffe E, Gannon CM, Gnudi L, White KE, Yancopoulos GD, Rudge JS, Woolf AS: Angiopoietin-1 therapy enhances fibrosis and inflammation following folic acid-induced acute renal injury. Kidney Int 2008, 74:300-309.

141. Lemieux C, Maliba R, Favier J, Theoret JF, Merhi Y, Sirois MG: Angiopoietins can directly activate endothelial cells and neutrophils to promote proinflammatory responses. Blood 2005, 105:1523-1530.

142. Aplin AC, Gelati M, Fogel E, Carnevale E, Nicosia RF: Angiopoietin-1 and vascular endothelial growth factor induce expression of inflammatory cytokines before angiogenesis. Physiol Genomics 2006, 27:20-28.

143. Rizkalla B, Forbes JM, Cooper ME, Cao Z: Increased renal vascular endothelial growth factor and angiopoietins by angiotensin II infusion is mediated by both AT1 and AT2 receptors. J Am Soc Nephrol 2003, 14:3061-3071

144. Kitayama H, Maeshima Y, Takazawa Y, Yamamoto Y, Wu Y, Ichinose $K$, Hirokoshi K, Sugiyama H, Yamasaki Y, Makino H: Regulation of angiogenic factors in angiotensin II infusion model in association with tubulointerstitial injuries. Am J Hypertens 2006, 19:718-727.

145. Fiedler U, Reiss Y, Scharpfenecker M, Grunow V, Koidl S, Thurston G, Gale NW, Witzenrath M, Rosseau S, Suttorp N, Sobke A, Herrmann M, Preissner KT, Vajkoczy P, Augustin HG: Angiopoietin-2 sensitizes endothelial cells to TNF-alpha and has a crucial role in the induction of inflammation. Nat Med 2006, 12:235-239.

146. Peters H, Border WA, Noble NA: Angiotensin II blockade and low-protein diet produce additive therapeutic effects in experimental glomerulonephritis. Kidney Int 2000, 57:1493-1501.

147. Wenzel UO, Thaiss F, Helmchen U, Stahl RA, Wolf G: Angiotensin II infusion ameliorates the early phase of a mesangioproliferative glomerulonephritis. Kidney Int 2002, 61:1020-1029.

148. Takazawa Y, Maeshima Y, Kitayama H, Yamamoto Y, Kawachi H, Shimizu F, Matsui $H$, Sugiyama $H$, Yamasaki Y, Makino H: Infusion of angiotensin-II reduces loss of glomerular capillary area in the early phase of anti-Thy-1 nephritis possibly via regulating angiogenesis-associated factors. Kidney Int 2005, 68:704-722.

149. Hirokoshi K, Maeshima Y, Kobayashi K, Matsuura E, Sugiyama H, Yamasaki Y, Masuyama $\mathrm{H}$, Hiramatsu $Y$, Makino $\mathrm{H}$ : Increase of serum angiopoietin-2 during pregnancy is suppressed in women with preeclampsia. Am J Hypertens 2005, 18:(9 Pt 1):1181-8

150. Lim HS, Lip GY, Blann AD: Angiopoietin-1 and angiopoietin-2 in diabetes mellitus: relationship to VEGF, glycaemic control, endothelial damage/ dysfunction and atherosclerosis. Atherosclerosis 2005, 180:113-118.

151. Lee S, Kim W, Moon SO, Sung MJ, Kim DH, Kang KP, Jang KY, Lee SY, Park BH, Koh GY, Park SK: Renoprotective effect of COMP-angiopoietin-1 in $\mathrm{db} / \mathrm{db}$ mice with type 2 diabetes. Nephrol Dial Transplant 2007, 22:396-408.

152. Carmeliet P: Mechanisms of angiogenesis and arteriogenesis. Nat Med 2000, 6:389-395.

153. Wu Q, Du Y, Yang N, Liang Y, Li Y: Microvasculature change and placenta growth factor expression in the early stage of a rat remnant kidney model. Am J Nephrol 2006, 26:97-104.

154. O'Reilly MS, Holmgren L, Shing Y, Chen C, Rosenthal RA, Moses M, Lane WS, Cao Y, Sage EH, Folkman J: Angiostatin: a novel angiogenesis inhibitor that mediates the suppression of metastases by a Lewis lung carcinoma [see comments]. Cell 1994, 79:315-328.

155. Basile DP, Fredrich K, Weihrauch D, Hattan N, Chilian WM: Angiostatin and matrix metalloprotease expression following ischemic acute renal failure. Am J Physiol Renal Physiol 2004, 286:F893-902.

156. Mu W, Long DA, Ouyang $X$, Agarwal A, Cruz PE, Roncal CA, Nakagawa T, Yu X, Hauswirth WW, Johnson RJ: Angiostatin overexpression is associated with an improvement in chronic kidney injury by an antiinflammatory mechanism. Am J Physiol Renal Physiol 2009, 296:F145-152.

157. Hudson BG, Reeders ST, Tryggvason K: Type IV collagen: structure, gene organization, and role in human diseases. Molecular basis of Goodpasture and Alport syndromes and diffuse leiomyomatosis. J Biol Chem 1993, 268:26033-26036.

158. Maeshima Y, Colorado PC, Torre A, Holthaus KA, Grunkemeyer JA, Ericksen MB, Hopfer H, Xiao Y, Stillman IE, Kalluri R: Distinct antitumor properties of a type IV collagen domain derived from basement membrane. J Biol Chem 2000, 275:21340-21348.

159. Petitclerc E, Boutaud A, Prestayko A, Xu J, Sado Y, Ninomiya Y, Sarras MP, Hudson BG, Brooks PC: New Functions for Non-collagenous Domains of 
Human Collagen Type IV. Novel integrin ligands inhibiting angiogenesis and tumor growth in vivo. J Biol Chem 2000, 275:8051-8061.

160. Hamano Y, Zeisberg M, Sugimoto H, Lively JC, Maeshima Y, Yang C, Hynes RO, Werb Z, Sudhakar A, Kalluri R: Physiological levels of tumstatin, a fragment of collagen IV alpha3 chain, are generated by MMP-9 proteolysis and suppress angiogenesis via alphaV beta3 integrin. Cancer Cell 2003, 3:589-601.

161. Maeshima Y, Colorado PC, Kalluri R: Two RGD-independent alpha vbeta 3 integrin binding sites on tumstatin regulate distinct anti-tumor properties. J Biol Chem 2000, 275:23745-23750.

162. Eikesdal HP, Sugimoto H, Birrane G, Maeshima Y, Cooke VG, Kieran M, Kalluri R: Identification of amino acids essential for the antiangiogenic activity of tumstatin and its use in combination antitumor activity. Proc Natl Acad Sci USA 2008, 105:15040-15045.

163. Kalluri R, Sun MJ, Hudson BG, Neilson EG: The Goodpasture autoantigen. Structural delineation of two immunologically privileged epitopes on alpha3(IV) chain of type IV collagen. J Biol Chem 1996, 271:9062-9068.

164. Hellmark T, Burkhardt H, Wieslander J: Goodpasture disease. Characterization of a single conformational epitope as the target of pathogenic autoantibodies. J Biol Chem 1999, 274:25862-25868.

165. Maeshima Y, Manfredi M, Reimer C, Holthaus KA, Hopfer H, Chandamuri BR, Kharbanda S, Kalluri R: Identification of the anti-angiogenic site within vascular basement membrane-derived tumstatin. J Biol Chem 2001, 276:15240-15248.

166. Maeshima Y, Yerramalla UL, Dhanabal M, Holthaus KA, Barbashov S, Kharbanda S, Reimer C, Manfredi M, Dickerson WM, Kalluri R: Extracellular matrix-derived peptide binds to alpha(v)beta(3) integrin and inhibits angiogenesis. J Biol Chem 2001, 276:31959-31968.

167. Maeshima Y, Sudhakar A, Lively JC, Ueki K, Kharbanda S, Kahn CR, Sonenberg N, Hynes RO, Kalluri R: Tumstatin, an endothelial cell-specific inhibitor of protein synthesis. Science 2002, 295:140-143.

168. Kestila M, Lenkkeri U, Mannikko M, Lamerdin J, McCready P, Putaala H, Ruotsalainen V, Morita T, Nissinen M, Herva R, Kashtan CE, Peltonen L, Holmberg C, Olsen A, Tryggvason K: Positionally cloned gene for a novel glomerular protein-nephrin-is mutated in congenital nephrotic syndrome. Mol Cell 1998, 1:575-582.

169. O'Reilly MS, Boehm T, Shing Y, Fukai N, Vasios G, Lane WS, Flynn E, Birkhead JR, Olsen BR, Folkman J: Endostatin: an endogenous inhibitor of angiogenesis and tumor growth. Cell 1997, 88:277-285.

170. Yamaguchi N, Anand-Apte B, Lee M, Sasaki T, Fukai N, Shapiro R, Que I, Lowik C, Timpl R, Olsen BR: Endostatin inhibits VEGF-induced endothelial cell migration and tumor growth independently of zinc binding. Embo J 1999, 18:4414-4423.

171. Hanai J, Dhanabal M, Karumanchi SA, Albanese C, Waterman M, Chan B, Ramchandran R, Pestell R, Sukhatme VP: Endostatin causes G1 arrest of endothelial cells through inhibition of cyclin D1. J Biol Chem 2002, 277:16464-16469.

172. Hajitou A, Grignet C, Devy L, Berndt S, Blacher S, Deroanne CF, Bajou K, Fong T, Chiang Y, Foidart JM, Noel A: The antitumoral effect of endostatin and angiostatin is associated with a down-regulation of vascular endothelial growth factor expression in tumor cells. Faseb J 2002, 16:1802-1804.

173. Matsuno H, Yudoh K, Uzuki M, Nakazawa F, Sawai T, Yamaguchi N, Olsen BR, Kimura T: Treatment with the angiogenesis inhibitor endostatin: a novel therapy in rheumatoid arthritis. J Rheumatol 2002, 29:890-895.

174. Takahashi K, Saishin Y, Silva RL, Oshima Y, Oshima S, Melia M, Paszkiet B, Zerby D, Kadan MJ, Liau G, Kaleko M, Connelly S, Luo T, Campochiaro PA: Intraocular expression of endostatin reduces VEGF-induced retinal vascular permeability, neovascularization, and retinal detachment. Faseb J 2003, 17:896-898

175. Tanabe K, Maeshima Y, Ichinose K, Kitayama H, Takazawa Y, Hirokoshi K, Kinomura M, Sugiyama H, Makino H: Endostatin peptide, an inhibitor of angiogenesis, prevents the progression of peritoneal sclerosis in a mouse experimental model. Kidney Int 2007, 71:227-238.

176. Cattaneo MG, Pola S, Francescato P, Chillemi F, Vicentini LM: Human endostatin-derived synthetic peptides possess potent antiangiogenic properties in vitro and in vivo. Exp Cell Res 2003, 283:230-236.

177. Sudhakar A, Sugimoto H, Yang C, Lively J, Zeisberg M, Kalluri R: Human tumstatin and human endostatin exhibit distinct antiangiogenic activities mediated by alpha $v$ beta 3 and alpha 5 beta 1 integrins. Proc Natl Acad Sci USA 2003, 100:4766-4771.

178. Karumanchi SA, Jha V, Ramchandran R, Karihaloo A, Tsiokas L, Chan B, Dhanabal M, Hanai JI, Venkataraman G, Shriver Z, Keiser N, Kalluri R, Zeng H, Mukhopadhyay D, Chen RL, Lander AD, Hagihara K, Yamaguchi Y, Sasisekharan R, Cantley L, Sukhatme VP: Cell surface glypicans are lowaffinity endostatin receptors. Mol Cell 2001, 7:811-822.

179. Nakashima T, Hirano S, Agata N, Kumagai H, Isshiki K, Yoshioka T, Ishizuka M, Maeda K, Takeuchi T: Inhibition of angiogenesis by a new isocoumarin, NM-3. J Antibiot (Tokyo) 1999, 52:426-428.

180. Reimer CL, Agata N, Tammam JG, Bamberg M, Dickerson WM, Kamphaus GD, Rook SL, Milhollen M, Fram R, Kalluri R, Kufe D, Kharbanda S: Antineoplastic effects of chemotherapeutic agents are potentiated by NM-3, an inhibitor of angiogenesis. Cancer Res 2002, 62:789-795.

181. Agata N, Nogi H, Bamberg M, Milhollen M, Pu M, Weitman S, Kharbanda S, Kufe D: The angiogenesis inhibitor NM-3 is active against human NSCLC xenografts alone and in combination with docetaxel. Cancer Chemother Pharmacol 2005, 56:610-614.

182. Wang JJ, Zhang SX, Lu K, Chen Y, Mott R, Sato S, Ma JX: Decreased expression of pigment epithelium-derived factor is involved in the pathogenesis of diabetic nephropathy. Diabetes 2005, 54:243-250.

183. Wang JJ, Zhang SX, Mott R, Chen Y, Knapp RR, Cao W, Ma JX: Antiinflammatory effects of pigment epithelium-derived factor in diabetic nephropathy. Am J Physiol Renal Physiol 2008, 294:F1166-1173.

184. Watanabe K, Hasegawa Y, Yamashita H, Shimizu K, Ding Y, Abe M, Ohta H, Imagawa K, Hojo K, Maki H, Sonoda H, Sato Y: Vasohibin as an endothelium-derived negative feedback regulator of angiogenesis. J Clin Invest 2004, 114:898-907.

185. Yamashita H, Abe M, Watanabe K, Shimizu K, Moriya T, Sato A, Satomi S, Ohta $\mathrm{H}$, Sonoda $\mathrm{H}$, Sato $\mathrm{Y}$ : Vasohibin prevents arterial neointimal formation through angiogenesis inhibition. Biochem Biophys Res Commun 2006, 345:919-925.

186. Shen J, Yang X, Xiao WH, Hackett SF, Sato Y, Campochiaro PA: Vasohibin is up-regulated by VEGF in the retina and suppresses VEGF receptor 2 and retinal neovascularization. Faseb J 2006, 20:723-725.

187. Yoshinaga K, Ito K, Moriya T, Nagase S, Takano T, Niikura H, Yaegashi N, Sato $Y$ : Expression of vasohibin as a novel endothelium-derived angiogenesis inhibitor in endometrial cancer. Cancer Sci 2008, 99:914-919.

188. Miyake K, Nishida K, Kadota Y, Yamasaki H, Nasu T, Saitou D, Tanabe K, Sonoda $H$, Sato $Y$, Maeshima Y, Makino H: Inflammatory cytokine-induced expression of vasohibin-1 by rheumatoid synovial fibroblasts. Acta Med Okayama 2009, 63:349-358.

189. Kimura H, Miyashita H, Suzuki Y, Kobayashi M, Watanabe K, Sonoda H, Ohta H, Fujiwara T, Shimosegawa T, Sato Y: Distinctive localization and opposed roles of vasohibin-1 and vasohibin-2 in the regulation of angiogenesis. Blood 2009.

190. Kosugi T, Nakayama T, Li Q, Chiodo VA, Zhang L, Campbell-Thompson M, Grant M, Croker BP, Nakagawa T: Soluble Flt-1 gene therapy ameliorates albuminuria but accelerates tubulointerstitial injury in diabetic mice. Am J Physiol Renal Physiol 298:F609-616.

191. Nangaku M: Chronic hypoxia and tubulointerstitial injury: a final common pathway to end-stage renal failure. J Am Soc Nephrol 2006, 17:17-25.

192. Heishi T, Hosaka T, Suzuki Y, Miyashita H, Oike Y, Takahashi T, Nakamura T, Arioka S, Mitsuda Y, Takakura T, Hojo K, Matsumoto M, Yamauchi C, Ohta H, Sonoda $\mathrm{H}$, Sato Y: Endogenous angiogenesis inhibitor vasohibin1 exhibits broad-spectrum antilymphangiogenic activity and suppresses lymph node metastasis. Am J Pathol 176:1950-1958.

doi:10.1186/1755-1536-3-13

Cite this article as: Maeshima and Makino: Angiogenesis and chronic kidney disease. Fibrogenesis \& Tissue Repair 2010 3:13. 